Portland State University

PDXScholar

5-23-1997

\title{
The Periphyton Community of a Second Order Subalpine Stream Following Salmon Carcass Decomposition
}

Jonathan Micheal Honea

Portland State University

Follow this and additional works at: https://pdxscholar.library.pdx.edu/open_access_etds

Part of the Biology Commons

Let us know how access to this document benefits you.

Recommended Citation

Honea, Jonathan Micheal, "The Periphyton Community of a Second Order Subalpine Stream Following Salmon Carcass Decomposition" (1997). Dissertations and Theses. Paper 5360.

https://doi.org/10.15760/etd.7233

This Thesis is brought to you for free and open access. It has been accepted for inclusion in Dissertations and Theses by an authorized administrator of PDXScholar. Please contact us if we can make this document more accessible: pdxscholar@pdx.edu. 


\section{THESIS APPROVAL}

The abstract and thesis of Jonathan Michael Honea for the Master of Arts in Biology were presented May 23, 1997, and accepted by the thesis committee and the department.

COMMITTEE APPROVALS:

Richard Petersen, Chair

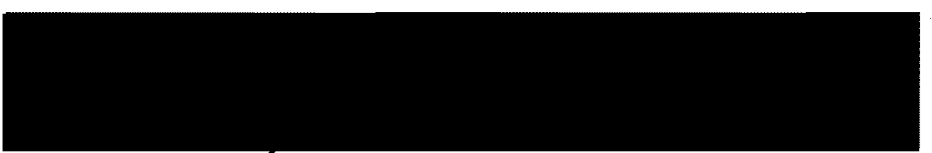

Robert Tinnin

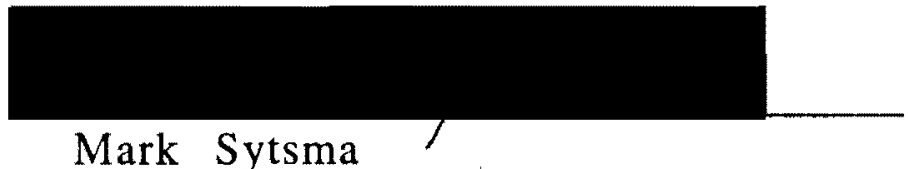

Mark Sytsma

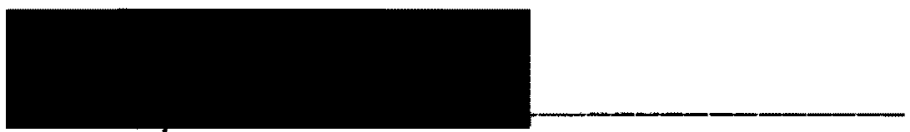

Jamres Pratt

Representative of the Office of

DEPARTMENT APPROVAL:

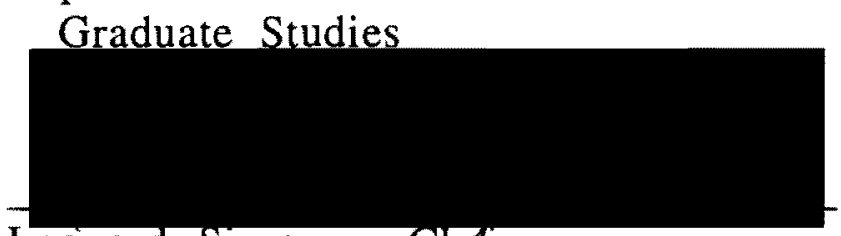

Leonard Simpson, Chấr

Department of Biology

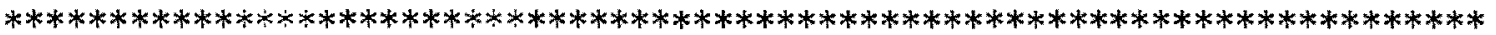

ACCEPTED FOR PORTLAND STATE UNIVERSITY BY THE LIBRARY

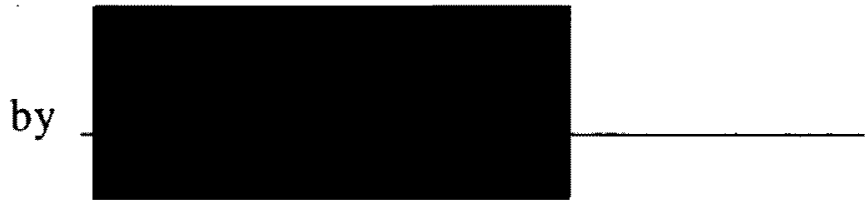

on

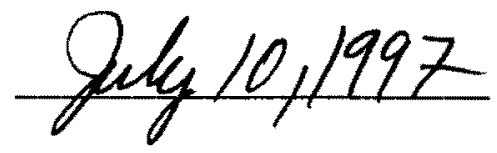




\section{ABSTRACT}

An abstract of the thesis of Jonathan Michael Honea for the Master of Arts in Biology presented May 23, 1997.

Title: The Periphyton Community of a Second Order Subalpine Stream Following Salmon Carcass Decomposition: a potential facilitator of the energy flow from adult to juvenile salmonids.

To protect and manage Pacific Northwest salmonid stocks, sound management programs must be developed that incorporate knowledge of the ecological processes critical to their survival. One such process is the nutrient dynamic in headwater spawning streams. It is essential that we understand the trophic relationships among the spawners, the 1 to 3 year-old juveniles, the invertebrates, and the primary producers in these streams.

The hypothesis that I tested is that photoautotrophic production increases due to the decomposition of salmon carcasses. Increased primary production would stimulate the production of invertebrates which are an important food resource of juvenile salmonid species. The hypothesis was tested by comparing periphyton communities sampled from upstream reference sites with those sampled from sites within and downstream of a onemile reach of Still Creek, a stream within the Zigzag Ranger District of the Mount Hood National Forest, in which approximately 300 
coho (Oncorhynchus kisutch) carcasses were distributed.

Comparisons were based on the numbers of each diatom species observed and periphyton biomass measured as chlorophyll $a$ concentration and mass of organic matter lost on ignition. To more accurately characterize the response of the periphyton community, base-line data were collected before enrichment ascertaining the initial degree of nutrient limitation and measuring the variation within and among sample sites prior to site modification. Nutrient concentration and physical characteristics of the water were also monitored.

The data collected indicate that the periphyton communities at each site were similar before carcass enrichment. After enrichment, treatment sites showed an increase in periphyton biomass. No change in species composition was observed from reference to treatment sites during the enrichment.

Some suggestions are made for improving the experimental design to better characterize the response of the periphyton community to salmon carcass decomposition, such as increasing sample size, adding more "before treatment" sample times, and adding a second treatment stream. 
THE PERIPHYTON COMMUNITY OF A SECOND ORDER SUBALPINE STREAM FOLLOWING SALMON CARCASS DECOMPOSITION:

A POTENTIAL FACILITATOR OF THE ENERGY FLOW

FROM ADULT TO JUVENILE SALMONIDS

b y

JONATHAN MICHAEL HONEA

A thesis submitted in partial fulfillment of the requirements for the degree of

MASTER OF ARTS

in

BIOLOGY

Portland State University

1997 


\section{ACKNOWLEDGMENTS}

This project was headed by the USFS, Zigzag Ranger District, Mt. Hood National Forest and the ODFW, Lower Willamette District, Columbia Region. The assistance of USFS personnel-Molly Sullivan, Jill North, Allen Smart and Chris Brigham-is greatly appreciated.

Analytical data of the water nutrients were provided by the Cooperative Chemical Analytical Laboratory. Cam Jones, CCAL Director, was especially helpful.

My fellow students, graduate and undergraduate, were a constant source of support. Thanks Jon Moulton, Chris Dobson, Jared May, Shannon Hubler, Zach Oestreicher, Keith Perkins, Nancy Scott, Sue Weston, and all the rest of you.

I will always be in debt to the professors, researchers and instructors here at Portland State University who have shared their experience and kindness with me. I am deeply grateful to Drs. Pan Yangdong, Mary Taylor, Nancy Bowers, John Rueter, Dick Forbes, Herman Taylor, Ian Waite and others.

My committee members gave much to me, not only in helping me to appreciate this project but also supporting me in classes and work. Thank you very much Drs. Richard Petersen, Bob Tinnin, Mark Sytsma and Dick Pratt.

I would also like to thank my uncle, Don Carolan, for encouraging me to come to Portland and taking good care of me.

And my deepest thanks to Kayoko Hishiyama, my wife, for her patience, support and love. 


\section{TABLE OF CONTENTS}

page

Acknowledgments ..................... ii

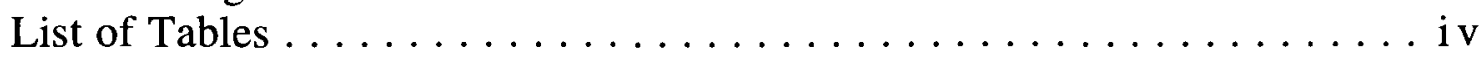

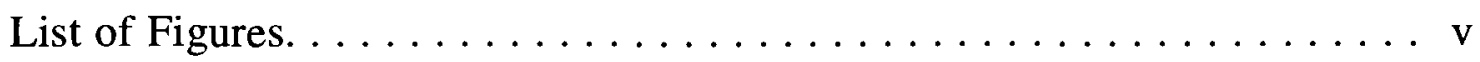

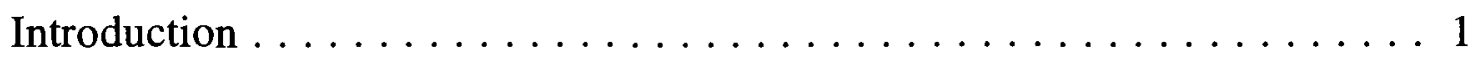

Description of Project $\ldots \ldots \ldots \ldots \ldots \ldots \ldots \ldots \ldots \ldots \ldots \ldots \ldots \ldots$

Methods .......................... 7

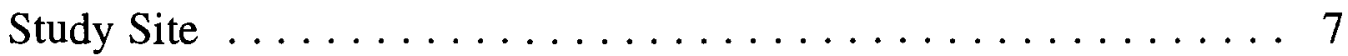

Physical and chemical variables . . . . . . . . . . . 11

Pre-treatment nutrient diffusion experiment ........11

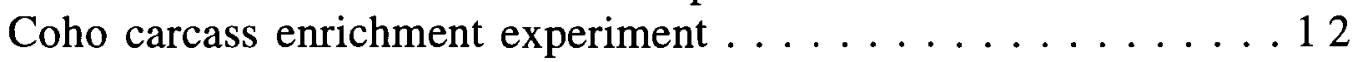

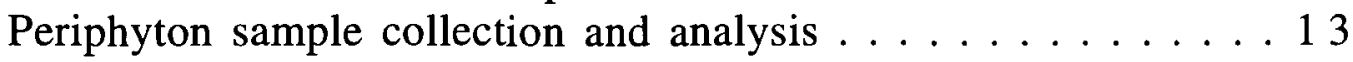

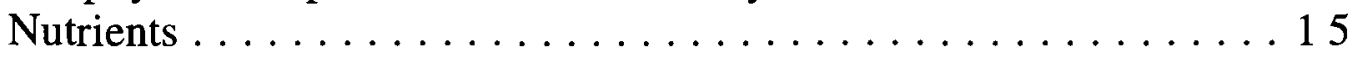

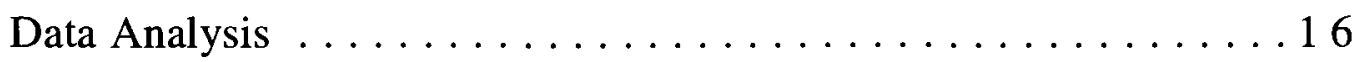

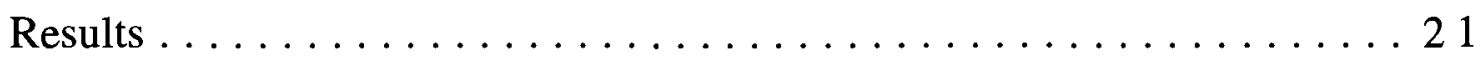

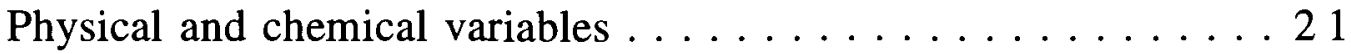

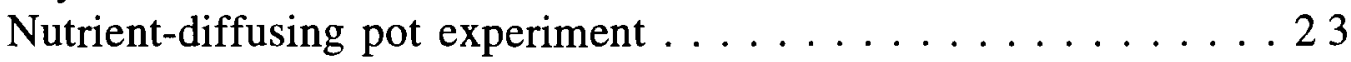

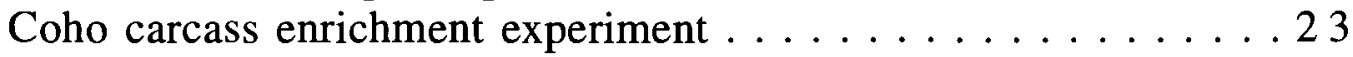

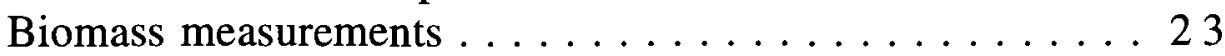

Diatom community composition . . . . . . . . 34

Analysis of nutrients in water ........... 39

Discussion ............................ 39

Weaknesses and anomalies in the study .........44

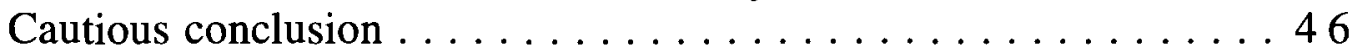

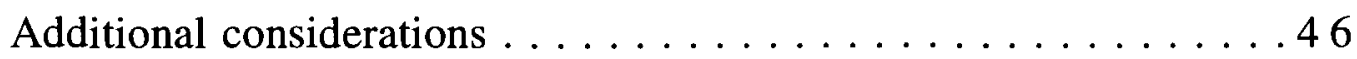

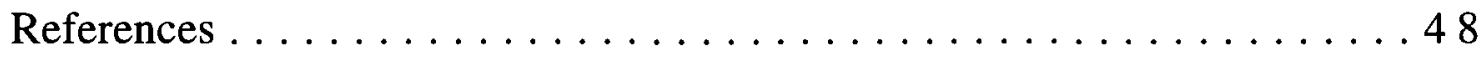

Appendices

One $\quad$ Water chemistry ................ 53

Two Diatom taxa of Still Creek: list of taxa . . . . . 55

Three A Diatom taxa of Still Creek: scanning electron

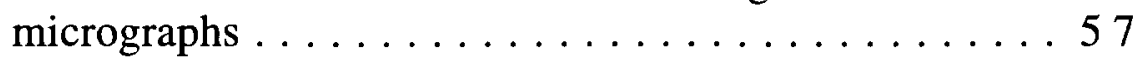

Three B Diatom taxa of Still Creek: video graphic prints . .60 
List of Tables

Table

page

1 Temporal pattern of coho carcass distribution . . . . . . 13

2 Results of water nutrient analysis . . . . . . . . 39 


\section{List of Figures}

Figure

page

1 Sandy River Subbasin $\ldots \ldots \ldots \ldots \ldots \ldots \ldots$

2 Immediate region around Still Creek . . . . . . . . . 9

3 Diagram of sample sites $\ldots \ldots \ldots \ldots \ldots \ldots \ldots \ldots \ldots$

4 Average water depth at sample sites . . . . . . . 21

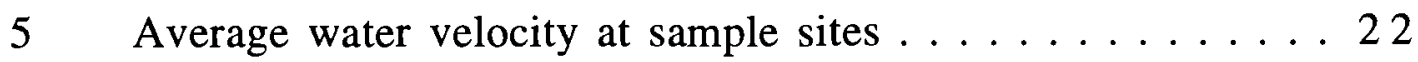

6 Percent overstory cover $\ldots \ldots \ldots \ldots \ldots \ldots \ldots \ldots \ldots \ldots \ldots$

7 Site 1 biomass data from nutrient-diffusing pot

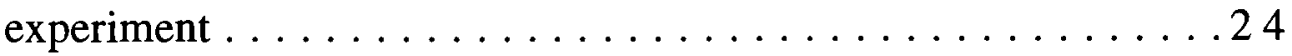

8 Site 2 biomass data from nutrient-diffusing pot

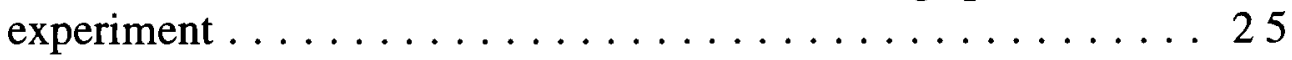

9 Site 3 biomass data from nutrient-diffusing pot

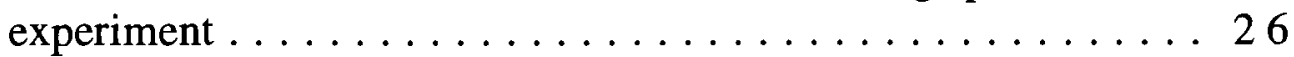

10 Site 4 biomass data from nutrient-diffusing pot

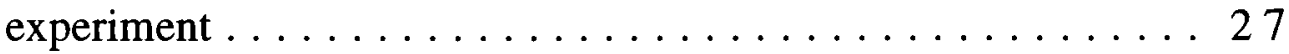

11 Site 5 biomass data from nutrient-diffusing pot

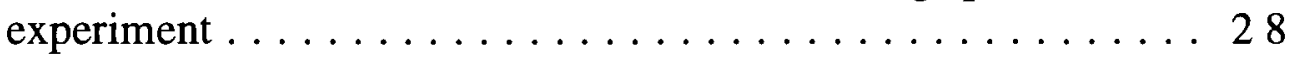

12 Biomass data before carcass enrichment (9-23-96) . . . 30

13 Biomass data after four weeks of carcass enrichment

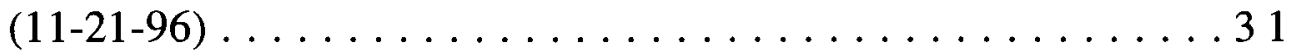

14 Biomass data after six weeks of carcass enrichment

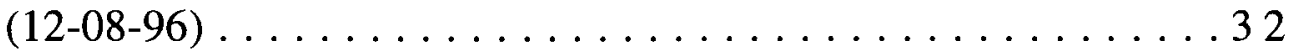

15 Biomass data after eight weeks of carcass enrichment

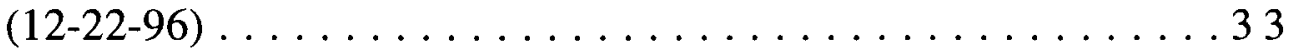


16 Cluster from Euclidean distance resemblance coefficients of original data . . . . . . . . . . . . . . . . . .

17 Cluster from Euclidean distance resemblance coefficients

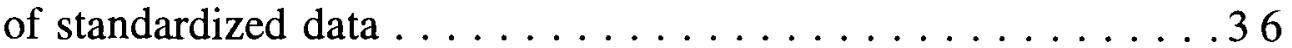

18 Cluster from Chord resemblance coefficients of original

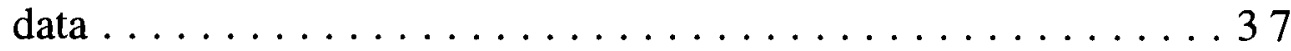

19 Cluster from Chord resemblance coefficients of standarized data $\ldots \ldots \ldots \ldots \ldots \ldots \ldots \ldots \ldots \ldots \ldots$ 


\section{INTRODUCTION}

Pacific Northwest salmonid populations have been decreasing at an alarming rate. Many anthropogenic factors are contributing to this decline. Commercial overfishing by many countries of the Pacific rim, including the US, Canada, Japan and Russia, greatly reduce their numbers (UN FAO 1979-93). Impoundment of rivers and streams not only creates a physical barrier to passage during migration to and from the oceans, it also decreases the rate of water flow. This reduced flow increases the energy demand for downstream travel by the smolt and may cause detrimental changes in these ecosystems including shifts in the trophic web that may limit prey or favor predators such as walleye, small-mouth bass and squawfish (Rieman et al. 1991). Large-scale changes in drainage basins from municipal development, timber-harvest, agriculture and grazing may result in an increase in sediment loading or temperature in spawning areas which has been found to reduce salmonid survival (Waldichuk 1993).

The plight of the Pacific Northwest salmonids is exacerbated by the El Niño effect which, most recently during 1995 and before that from 1991 through 1993, caused a shift in the ocean upwelling off the Pacific Northwest coast. This shift results in a decrease in the nutrients supporting the plankton that make up the base of the food web on which the juvenile salmonids depend. This shift in the upwelling also brings an increase in the water temperature allowing warmer-water predators such as mackerel to move north to feed on the juvenile salmonids (Kassoy 1996). 
To halt the decline of the Pacific Northwest salmonid populations, sound management programs must be developed that incorporate an understanding of the ecological roles of salmonids in each phase of their life cycle. One area that needs further research is the role of salmonids in the nutrient dynamics of their spawning streams. It is essential that we understand the trophic relationships among the spawners, the 1 to 3 year-old juveniles, the invertebrates and the primary producers in headwater spawning streams.

Cederholm et al. (1989) determined that only $8 \%$ of salmon carcasses placed in a spawning-stream were transported more than $300 \mathrm{~m}$ downstream. The great majority entered immediate stream and adjacent forest trophic webs. The anadromous salmonids therefore provide an enormous and regular infusion of marinederived nutrients (MDN) into the spawning bed area.

This nutrient infusion seems to benefit juveniles that may remain in the stream for up to three years after hatching. Bilby et al. (1993) found that juvenile coho salmon (Oncorhynchus kisutch) growth rate more than doubled following spawner decomposition in the Snoqualmie River system, Washington. Analysis of the fractionation of stable nitrogen and carbon isotopes revealed that the juveniles contained large amounts of marine-derived nitrogen and carbon (30.6\% and $39.5 \%$, respectively), supporting the conclusion that the stimulus of the increased growth was the nutrient release from the decomposing adult carcasses. Michael (1995), examining the interaction of two salmonid species spawning 
in the Skagit River, Washington, found a very strong positive correlation between the numbers and biomass of spawning pink salmon ( $O$. gorbuscha) and the numbers and biomass of returning coho which had been present in the stream as juveniles at the time the pinks were spawning.

Kline et al. (1990) postulated two pathways by which MDN from adult salmon may be transferred to the juveniles. The first results from the release of dissolved nutrients through the excretions of spawning adults and decomposition of adults after spawning. The second pathway results from direct consumption of eggs, fry and carcasses. Each pathway was elucidated by examining the fractionation of stable $\mathrm{N}$ and $\mathrm{C}$ isotopes in a stream system in southeastern Alaska during and following spawning by pink salmon. The first pathway postulated by Kline et al. was found to fertilize autochthonous production by periphyton, which in turn supported grazer caddisflies, which supported fish production including rainbow trout (O. mykiss), Dolly Varden (Salvelinus malma), coastrange sculpin (Cottus aleuticus) and coho juveniles. The second pathway supported the fish populations through direct consumption and indirectly through consumption of scavenging invertebrates including stonefly nymphs (also feeding on periphyton) and turbellarians. By using similar methods to compare oligotrophic lakes in a single watershed in southwestern Alaska with and without an anadromous salmon run, Kline et al. (1993) concluded that the major pathway of MDN from the returning sockeye (O. nerka) adults to the fry and juveniles is 
through remineralization of the carcasses stimulating photoautotrophic production and the flow of this energy throughout the food web.

Fisher-Wold and Hershey (1995) found evidence for the importance of the MDN pathway from adult salmon to smolt and fry via remineralization of the nutrients stimulating photoautotrophic production in a headwater stream in Minnesota. They used clay pots as artificial substrates for monitoring changes in the algal community. Although they found algal growth to be significantly enhanced, diatom diversity was not affected by carcass decomposition. Other research also supports the conclusion that the nutrient transfer occurs through stimulation of photoautotrophic production (Richey et al. 1975, Schuldt and Hershey 1995).

In other systems, evidence has been found supporting the greater relative importance of other pathways of MDN from adult salmonids through the stream trophic web to the juveniles. Bilby et al. (1993) proposed that secondary consumption was the most likely fate of MDN released by decomposing adult coho in their study of Pacific Northwest streams. They concluded that stimulation of photoautotrophic production was less important in their study because heavy shading in the headwater streams and the low water temperatures and high discharge typical of the region's winter months during which the carcasses are present are all factors which limit the growth of primary producers.

The pathway or pathways, as well as the relative importance of each pathway, that these nutrients take through the stream food 
web are shown by the above research to be dependent on interacting factors including season, hydraulic variables, stream location, and species makeup and relative abundances. Rand et al. (1992) make this point clear in their study of the effect of coho and chinook salmon (O. tshawytscha) spawning in Lake Ontario tributaries in New York State. These tributaries, unlike many western headwater streams are limited more by light than nutrients during the spring when thawing allows the salmon carcasses to decompose. For this reason primary production is not stimulated by the increase in nutrients from the decomposing carcasses. In addition, heavy fishing and the only recent reintroduction of anadromous salmonids to this region result in a much smaller spawning population than is typically studied in the west. This means that the nutrient transfer is small even via direct consumption of the carcasses.

Although there are exceptions, there is enough evidence to support the conclusion that in many headwater, spawning streams, the regular infusion of large quantities of MDN from the decomposition of adult salmonid carcasses supports the production of smolt. Not only does the MDN seem to increase smolt escapement size, but it also appears to lead to increased biomass per capita which may be necessary to give them a competitive and defensive advantage enroute to adulthood. This cycling of nutrients from generation to generation and year-class to year-class that is dependent on intact spawning stream trophic webs may be necessary in developing and maintaining salmon populations and 
this process should be prominent among the considerations when developing management plans.

\section{DESCRIPTION OF PROJECT}

The United States Forest Service, Zigzag Ranger District, Mt. Hood National Forest (USFS), and the Oregon Department of Fish and Wildlife, Lower Willamette District, Columbia Region (ODFW), initiated and managed a project to enrich a stream with salmon carcasses to test the hypothesis that salmon carcass decomposition provides a regular infusion of nutrients into spawning streams that stimulates production in the system. The goal was to identify whatever pathways of nutrient and energy flow that may exist from the adult salmon carcasses to the juveniles in a selected system.

My role in this study was to monitor any changes in the periphyton community of the stream following enrichment with salmon carcasses. The working hypothesis that $I$ tested is that photoautotrophic production increases following placement of the carcasses. Increased primary production would stimulate the production of invertebrates which are an important food resource of juvenile salmonid species (Nielsen 1992). Increased periphyton biomass would further tighten the downstream spiral of nutrients by taking up dissolved nutrients released as waste by macroinvertebrates. This would maintain the stimulatory effect of the carcasses on stream production near the spawning beds. 


\section{MEIHODS}

The hypothesis was tested by comparing periphyton sampled downstream from the enrichment site with those sampled upstream. Comparisons were based on the numbers of each diatom species observed and biomass measured as chlorophyll $a$ concentration and mass of organic matter lost on ignition. To more accurately characterize the response of the periphyton community, base-line data were collected before enrichment ascertaining the initial degree of nutrient limitation and measuring the variation within and among sample sites prior to site modification. Nutrient concentration and physical characteristics of the water were also monitored.

\section{Study Site}

Still Creek was selected as the site for this study. Still Creek is a tributary of the Zigzag River which in turn flows into the Sandy River, a major tributary of the Columbia River (Figure 1). It is a second order subalpine stream in the Zigzag Ranger District of the Mt. Hood National Forest. It drains Palmer Glacier on the south slope of Mt. Hood above the Timberine Lodge ski resort and flows west between Hunchback Mountain and Tom, Dick and Harry Mountain before turning northwest to merge with the Zigzag River. Marmot Dam built in the first decade of this century at river mile 30 on the Sandy River is the only significant physical obstacie to salmonid migration. It contains a fish ladder but minimum flows sufficient for salmonid passage (and downstream rearing) were not 
maintained by Portland General Electric until a 1970's Federal Energy Regulatory Commission licensing procedure required them to do so. Still Creek continues to support populations of coho, chinook and steelhead although they occur at populations far below estimates of historic numbers (Jill North, Zigzag Ranger District, personal communication).

Figure 1. Sandy River Subbasin

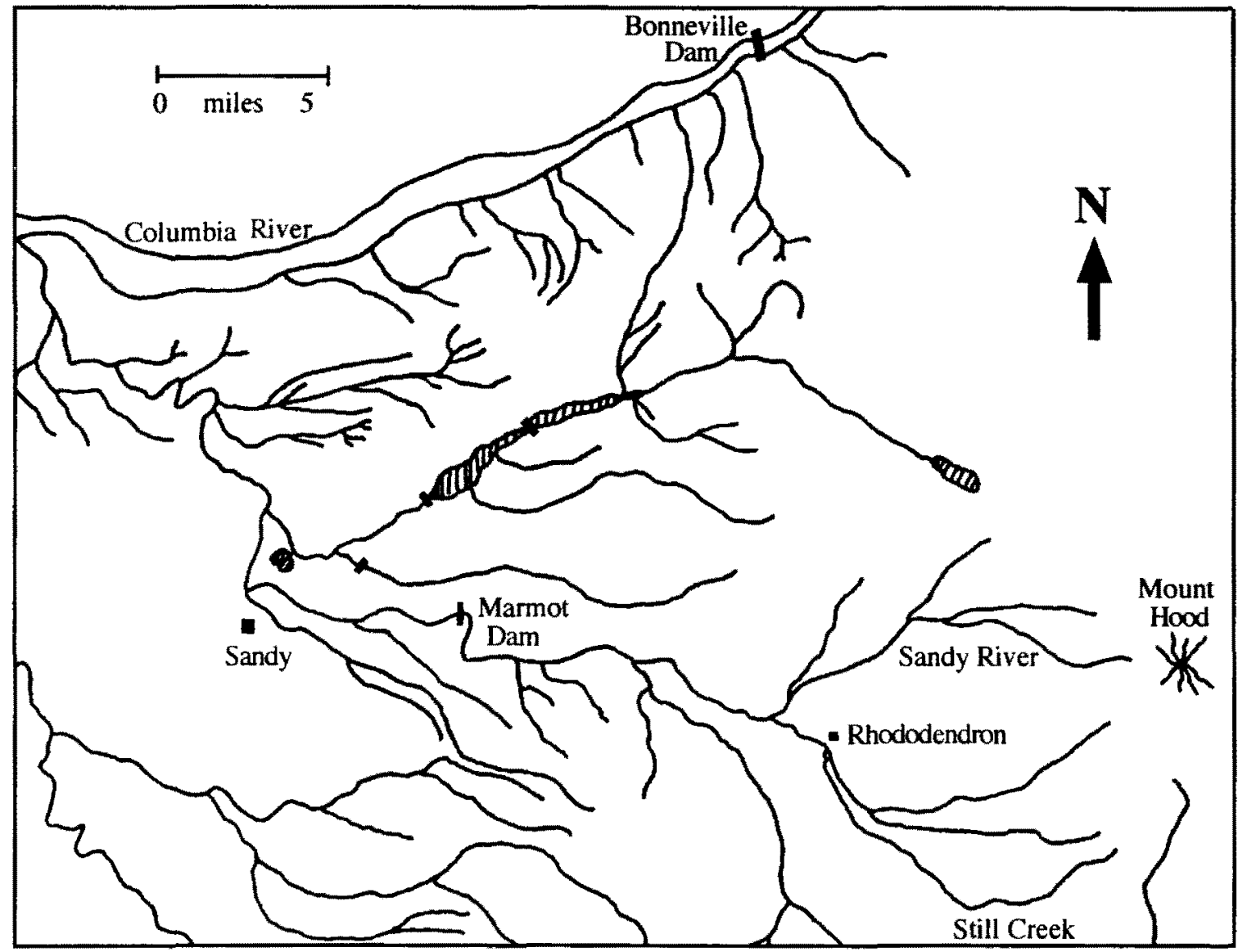

The upstream reference reach of Still Creek was river mile 4 to approximately 4.5 (Figure 2). Sample sites 1 and 2 were located 
there. River mile 3 to 4 was enriched with the salmon carcasses. Sample sites 3 and 4 were located in this reach and site 5 was located approximately $200 \mathrm{~m}$ downstream (Figure 3 ). The sites were chosen to be as alike as possible in terms of riparian cover, water velocity and depth, and substrate size.

Figure 2. Immediate region around Still Creek.

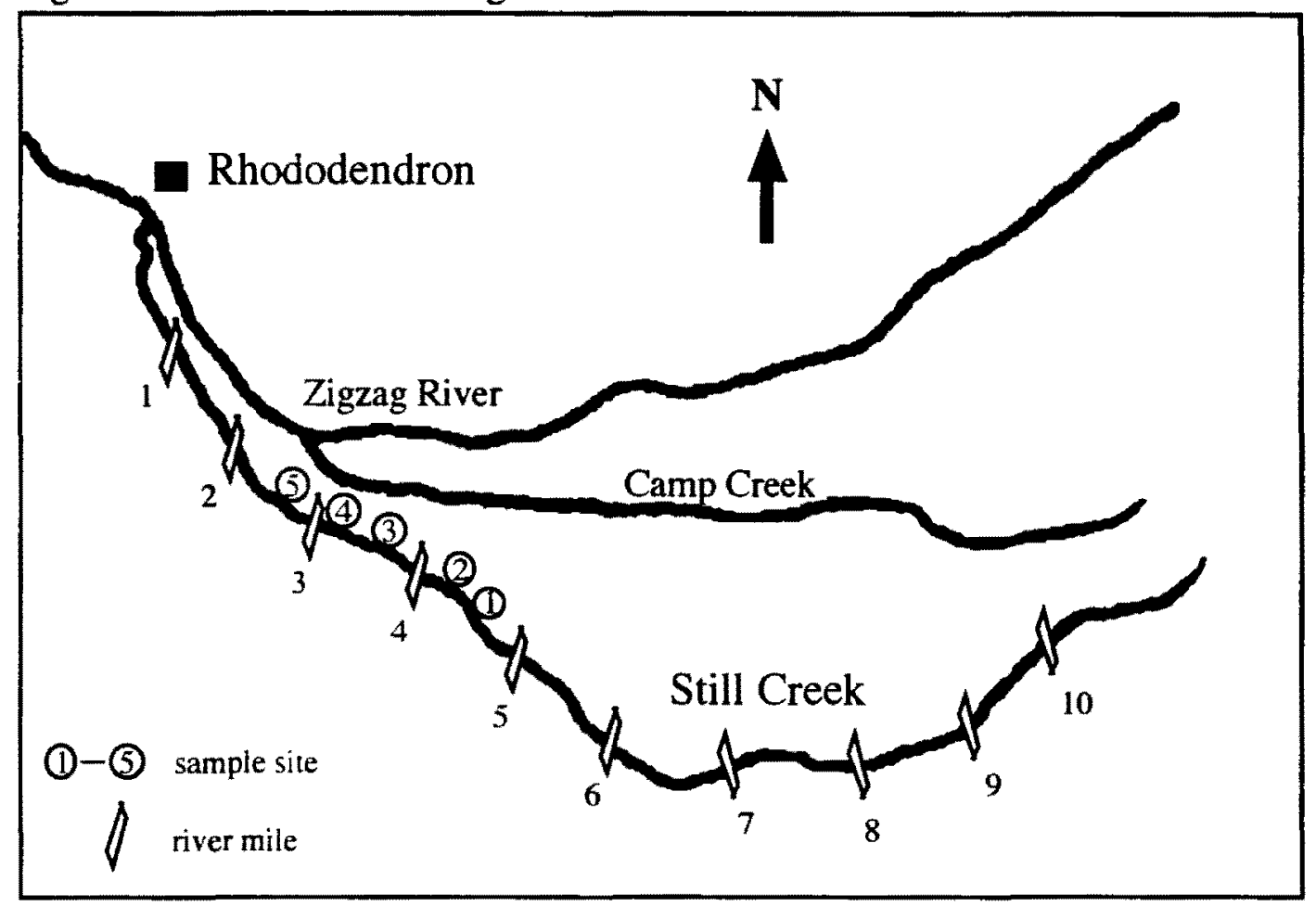


Figure 3. Diagram of sample sites.

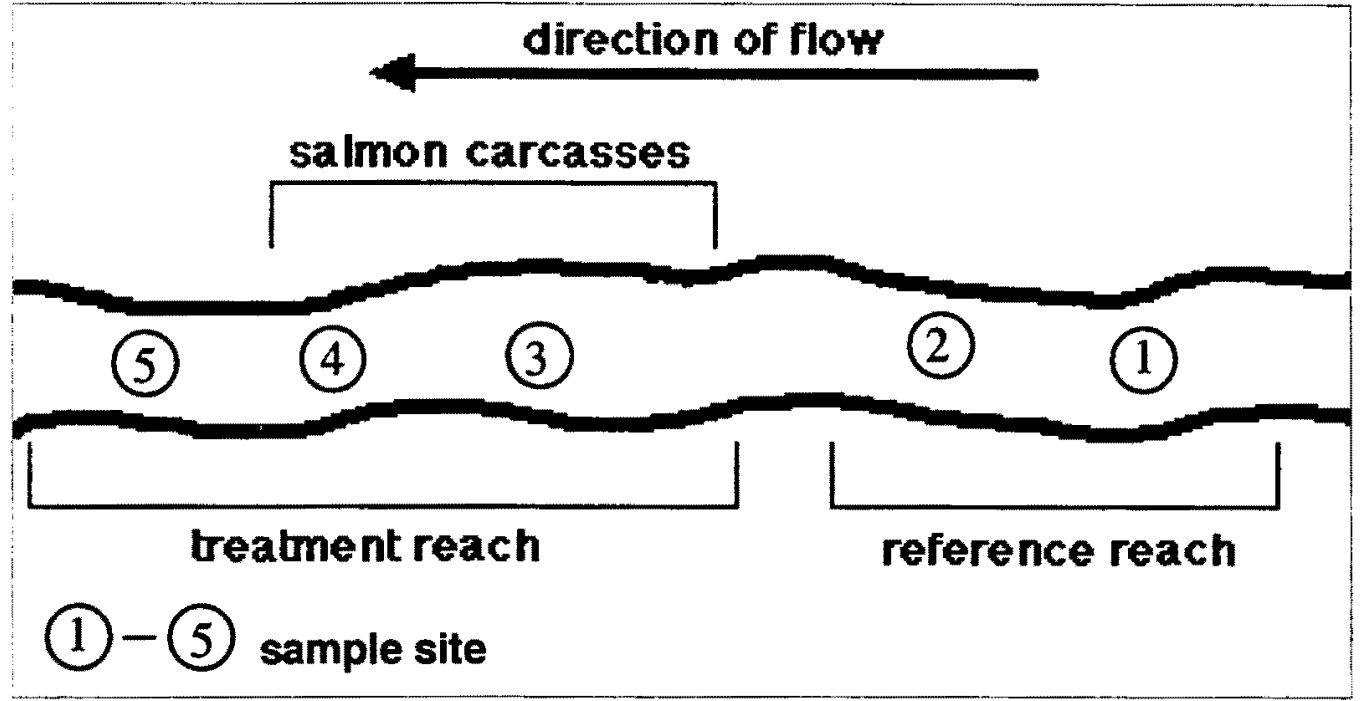

The study reach of Still Creek is at an altitude approximately $800 \mathrm{~m}$. The adjacent forest is dominated by western hemlock (Tsuga heterophylla (Raf.) (Sarg.)), but includes Douglas-fir (Pseudotsuga menziesii (Mirbel) (Franco)), western red cedar (Thuja plicata (Donn.)), devil's club (Oplopanax horridus (Smith) (Miq.)), sword fern (Polysticum munitum (Kaulf.) (Presl)), salal (Gaultheria shallon (Pursh)), Oregon grape (Berberis nervosa (Pursh)), redwood sorrel (Oxalis oregana (Nutt.)) and other vegetation characteristic of older second-growth in the damp areas of a Tsuga heterophylla Zone (Franklin and Dyrness 1988). Riparian vegetation includes red alder (Alnus rubra (Bong.)), big-leaf maple (Acer macrophyllum (Pursh)), vine maple (Acer circinatum (Pursh)), salmonberry (Rubus spectabilis (Pursh)), palmate coltsfoot (Petasites palmatus (Ait.) (Cronq.)) and a daisy (Erigeron sp. (L.)) (Hitchcock and Cronquist 1991). 


\section{Physical and chemical variables}

To evaluate the similarity of the sample sites, physical and chemical variables were measured at each site in conjunction with each sample date as well as just before the carcasses were placed, making a total of five occasions. A Swoffer model 200 flowmeter with a 2 in propeller was used to measure water depth and velocity at each site. Measurements were made at the center and on either side of the pots. A Hydrolab $\mathrm{H} 2 \mathrm{O}$ was used to measure temperature, dissolved oxygen, $\mathrm{pH}$, conductivity, turbidity and redox. Riparian cover was estimated visually before initially choosing the sites considering the path of the sun and the presense of deciduous versus evergreen vegetation and then again more quantitatively at the end of the study using a Forestry Suppliers, Inc. Model A spherical densiometer (24-square grid).

\section{Pre-treatment nutrient diffusion experiment}

To study nutrient-limitation in Still Creek before the carcasses were added, $I$ conducted an experiment using nutrient-diffusing pots (Fairchild and Lowe 1984). Small clay flower-pots were cleaned in $4 \% \mathrm{HCl}$ for $24 \mathrm{~h}$ and then soaked three times in deionized $\mathrm{H}_{2} \mathrm{O}$ for $24 \mathrm{~h}$ each time. A 7 in gutter spike was inserted through the hole in the bottom of each pot and glued (Devcon High Strength 2Ton Waterproof Crystal Clear Epoxy) in place such that the head was on the outside of the bottom of the pot. The pots were then filled with five different agar solutions: $0.1 \mathrm{M}$ acetate (as $\mathrm{NaC}_{2} \mathrm{H}_{3} \mathrm{O}_{2}$ ), $0.1 \mathrm{M}$ nitrate (as $\mathrm{NaNO}_{3}$ ), $0.1 \mathrm{M}$ phosphate (as $\mathrm{Na}_{2} \mathrm{HPO}_{4}$ ), $0.1 \mathrm{M}$ 
nitrate with $0.1 \mathrm{M}$ phosphate, and unamended agar as a control. These concentrations have been previously used in the sampling of oligotrophic lakes with nutrient-diffusing pot techniques (Fairchild and Lowe 1984, Marks and Lowe 1992, Barnese and Schelske 1994). I found only one instance where this technique was used with streams and the concentrations used were not noted (FisherWold and Hershey 1995). After the agar had solidified, a small petri-dish half with a hole drilled into the middle to accommodate the end of the spike was sealed over the mouth of the each pot with glue. In this manner, nutrients should diffuse only through the porous clay when the pots were immersed in water.

Four replicates of each treatment were placed at each of the five sample sites on Still Creek. At each site, the pots were placed in randomized blocks (four rows, four pots per row, each row containing one of each treatment-their order randomized earlier in the lab by flipping coins) and approximately $15 \mathrm{~cm}$ apart in an attempt to simultaneously avoid cross contamination yet keep the pots in the same habitat type in terms of current, depth, riparian cover and substrate type. I examined the pots after 30 days but since periphyton growth seemed sparse, I allowed them to remain and removed them after a total of 45 days.

\section{Coho carcass enrichment experiment}

Once a week for six weeks, beginning on Oct 21 , thawed coho carcasses from the Oxbow Hatchery on the Sandy River were distributed in the treatment reach of Still Creek by volunteers from 
the community and from Grant High School. Approximately 300 carcasses were seeded in a manner meant to emulate a natural spawning pattern with a smaller portion arriving first, followed by the largest mass and then a small number of stragglers arriving last (see Table 1). The carcasses were distributed evenly among five different habitat types: structure-associated, side channel, pool and edgewater. Coley Powers of Mt. Hood Community College monitored carcass movement and condition for six weeks after the carcasses were first seeded (Powers 1997).

Table 1. Temporal pattern of coho carcass distribution.

\begin{tabular}{clc|} 
Week & Date & Number of Carcasses \\
\hline 1 & Oct 21 & 20 \\
2 & Oct 28 & 30 \\
3 & Nov 4 & 60 \\
4 & Nov 12 & 00 \\
5 & Nov 18 & 60 \\
6 & Nov 25 & 30 \\
\hline
\end{tabular}

On Oct 24 , I placed enough unamended pots to take five replicates from each sample site three times. I only intended to take four replicates each time but wanted to insure against loss from curious hikers or the current. Each site was sampled at four, six and eight weeks after carcass placement.

\section{Periphyton sample collection and analysis}

I randomized pot selection by flipping coins in the lab and selecting pots from the placement diagrams I had sketched in my 
field journal. Each pot was removed from the stream and placed with stream water in IL nalgene bottles and kept on ice in the dark. Samples were immediately (approximately one hour after last sample collected) bought to the lab where the periphyton was removed with a toothbrush and distilled water. Each sample was homogenized for 5 seconds on low using a Waring automatic blender in order to break up periphyton clumps. Homogenized samples were filled to a known volume and then separated into three subsamples for analyses of chlorophyll $a$ content, ash-free dry mass, and species identification and relative abundance.

Chlorophyll $a$ subsamples were immediately filtered onto Whatman GF/F $25 \mathrm{~mm}$ glass microfiber filters and the filters placed in a fluorometry tube with $10 \mathrm{~mL}$ of $95 \%$ methanol to extract for 10 $12 \mathrm{~h}$ at $4^{\circ} \mathrm{C}$ (Marker 1972, Axler and Owen 1994). The extract was decanted into clean fluorometry tube and read in a Turner Designs model $10-005 R$ fluorometer before and after acidification/neutralization in order to measure the concentrations of both chlorophyll $a$ and pheophytin.

Subsamples for ash-free dry mass were immediately filtered onto precombusted, preweighed Whatman GF/F $47 \mathrm{~mm}$ glass microfiber filters and then stored until ash-free dry mass could be measured following APHA, AWWA \& WEF (1992).

Subsamples for diatom species identification and relative abundances were immediately preserved with Lugol's solution until they could be filtered onto Gelman GN-6 $25 \mathrm{~mm} 0.45 \mu \mathrm{m}$ membrane filters. After filtration, these filters were allowed to dry for 
approximately $24 \mathrm{~h}$. They were then each placed on a drop of Permount mounting solution on a glass slide. A second drop of Permount was placed on top of the filter and then a cover slip was sealed over the top. Initial species determination was made under 1000X magnification (oil immersion) using a Nikon Labophot binocular compound light microscope. Samples were given to Zack Oestreicher who took scanning electron micrographs of several diatom species (see Appendix 3a). Images of other diatom taxa were taken using an Olympus $\mathrm{BH}-2$ microscope and a Sony Video Graphic Printer UP 850 (see Appendix 3b). After acquiring familiarity with the taxa present, I proceeded with counts to the lowest taxonomic level possible (at least to genus, usually to species) at $400 \mathrm{X}$ magnification using the Nikon microscope.

\section{Nutrients}

One water sample each was collected from sites $2,3,4$ and 5 on the day before the coho carcasses were first placed in the stream. The samples were sent to Coffey Laboratories, Inc. for analysis for total phosphorus and total Kjeldahl nitrogen concentration following APHA, AWWA \& WEF (1992). One water sample each was collected from all the sites four weeks into the carcass enrichment. They were sent to the Cooperative Chemical Analytical Laboratory for analysis for total phosphorus, total Kjeldahl nitrogen, soluble reactive phosphorus, nitrate/nitrite and ammonium following APHA, AWWA \& WEF (1992) (A new lab was selected because the detection limits of the first had been too high 
for our low-nutrient samples). One water sample each was collected from sites $2,3,4$ and 5 during week six of the carcass enrichment. They were sent to the Cooperative Chemical Analytical Laboratory for analysis for total phosphorus and total Kjeldahl nitrogen.

I requested that samples be collected from all the sites on each date and that they be analyzed for soluble reactive phosphorus, nitrate/nitrite and ammonium each time, but the USFS was unable to provide the necessary funds. I believe the analyses for soluble reactive phosphorus, nitrate/nitrite and ammonium, as measures of dissolved nutrients, are important data for assessing periphyton growth because only the dissolved nutrients are immediately available for periphyton uptake. Total phosphorus and total Kjeldahl nitrogen include particulate matter and so are difficult to interpret in terms of periphyton growth.

\section{Data analysis}

The planners of this study did not anticipate the need to apply the treatment and monitoring regime to more than one stream. This has resulted in an absence of true replication (termed "pseudoreplication" by Hurlbert 1984) and therefore weakens any conclusions that might be drawn from the study. Hurlbert (1984) argues that in the absence of treatment replication, a statistical difference between locations reveals a difference between the locations only, not a difference that can be attributed to a particular 
treatment effect because "similar" locations cannot be expected to remain so over time even without the introduction of a treatment.

A Before-After Impact-Control (BACI) sample design (Stewart-Oaten et al. 1986) permits an evaluation of the effects of an unreplicated treatment by quantifying the similarity among sample sites before a treatment is initiated and then identifying change in the degree of the similarity among these sites after the treatment potentially impinges on a subset of them (here, sites 3,4 and 5). It attempts to overcome temporal confounding (after Hurlbert 1984) by sampling more than once before the treatment and more than once after the treatment to identify background trends of change among the sites and so be able to distinguish new trends coinciding with the treatment. Data from the control pots of the nutrient-diffusing pot experiment were used to assess the similarity among the sites before the carcasses were placed in the stream, therefore only one "before" sample was collected. The limitations caused by this will be discussed below. The design of Stewart-Oaten et al. was modified as advised in Underwood (1992) by including more than one upstream reference site to achieve a more robust measure of spatial and temporal trends among the sites.

Although this modified $\mathrm{BACI}$ design resolves as much as possible problems associated with an absence of treatment replication, the fact that this study was performed in one stream means that the sample sites are not strictly independent: a random event at any upstream site has the potential to affect downstream 
sites. This design therefore fails the assumptions necessary for parametric (e.g., ANOVA) or even nonparametric tests of comparison (e.g., Kruskal and Wallis H-test or Mann-Whitney Utest) (Kruskal and Wallis 1952, Sokal and Rohlf 1995).

Due to the problems in this study with applying inferential statistics to make quantitative comparisons, the ash-free dry mass and chlorophyll $a$ data were evaluated by calculating a distributionfree confidence interval based on Wilcoxon's signed rank test using reference data (Hollander and Wolfe 1973). A qualitative decision was then made that means of treatment data falling outside the confidence interval were likely to be different from the reference data. In the case of the nutrient-diffusing pot experiment, the reference data were the control pots and a confidence interval was calculated from control pot data at each site. For the carcass enrichment experiment, the reference data were the upstream reference sites and a confidence interval was calculated from reference site data for each sample period. When the sample size was too low ( $n=1$ or 2 ) to calculate the confidence interval as above, the confidence interval used was calculated from grouped reference data. In the case of the nutrient-diffusing pot experiment, control pot data from all sites were grouped. Such grouping was not necessary in the carcass enrichment experiment.

Various cluster analyses were performed on the diatom count data using the program Syntax. The purpose was to determine if the diatom community on each of the pots was grouped by site and 
by treatment. Using various methods to construct a dendrogram may yield results that are informative in their differing clusters. The first step in a hierarchical, agglomerative cluster analysis is to calculate a resemblance coefficient for the every possible pair of pots. I used both the Euclidean distance coefficient and the Chord coefficient. The former is sensitive to size displacements among groups so resemblance will be affected by differences in total individuals on each pot. The Chord coefficient avoids weighting common species and so will be more sensitive to changes in less common groups. It is the one most commonly used in ecological studies (Ludwig 1988).

The resemblance coefficients were calculated from the original data and from the data after standardization. Standardizing the data reduces the effect of size displacements among the groups (Romesburg 1984). The standardizing function used before the Euclidean distance coefficient was calculated is the one most commonly used: a data matrix (with the species as rows and the replicates within sites as columns) cell is subtracted by the average value for that species and the result is divided by the standard deviation of the values for that species (Romesburg 1984). The standardizing function applied to each cell of the data set before the Chord distance coefficient was calculated was $\log _{10}+1$ (Ludwig 1988).

In this way, four resemblance matrices were constructed: one for each resemblance coefficient (Euclidean distance and Chord distance) on both the original and standardized data sets. 
After a resemblance matrix is constructed from the resemblance coefficient calculations, the two closest groups are grouped forming the first cluster level. A new resemblance matrix is made incorporating the new group in place of the individual groups that were combined. Again the two closest groups of the new matrix are combined and the process is continued until all of the groups are combined. The clustering method that I used is the unweighted pair-group method using arithmetic averages (UPGMA). This method is the one most widely used by ecologists because it maximized the cophenetic correlation. With this method, a new group's resemblance coefficients are calculated by averaging the resemblance coefficients of the groups that were combined to form it (Romesburg 1984). A dendrogram may be constructed using the resemblance coefficients at each grouping level to delineate the height of each corresponding branch.

Finally, a coefficient of cophenetic correlation must be calculated. This measures the correlation between the dendrogram and the original resemblance matrix. As the sample units are grouped and new resemblance coefficients are calculated, some distortion occurs. If the coefficient of cophenetic correlation is calculated to be 0.8 or higher, with 1 signifying a perfect correlation, then the dendrogram is considered to be an acceptable characterization of the original resemblance matrix (Romesburg 1984). 


\section{RESULTS}

\section{Physical and chemical variables}

No trends were observed in average water depth at the sample sites over the experimental period (Figure 4). The reason that there is no trend of increase in depth with time despite the fact the rainy season began just as the carcass enrichment was beginning is that the pots sampled after the carcass enrichment had been placed closer to shore to prevent them from being swept away and to allow me to reach them safely as the current and depth increased.

Figure 4. Average Water Depth at Sample Sites.

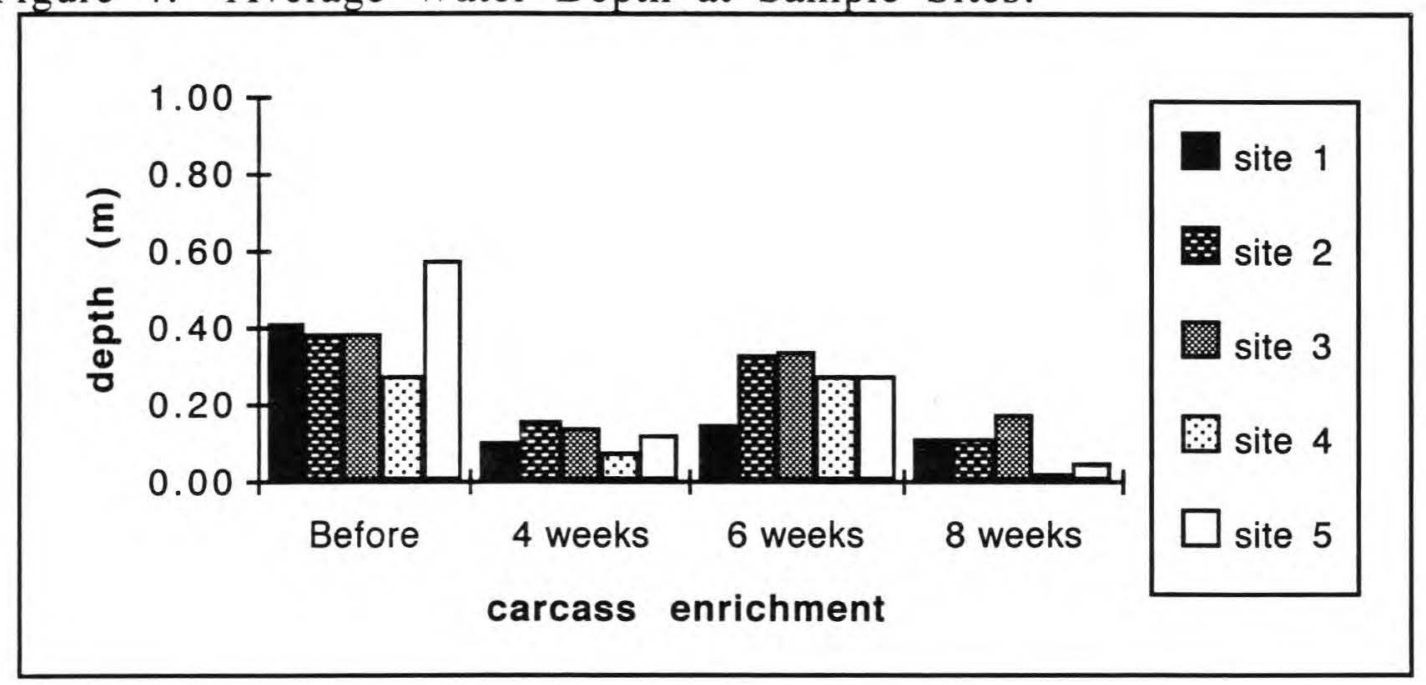

While there were initially no trends in average water velocity among the sample sites, the velocity at site 1 increased more than at the other sites when the rainy season began and flow began to increase in the stream (Figure 5). 
Figure 5. Average Water Velocity at Sample Sites.

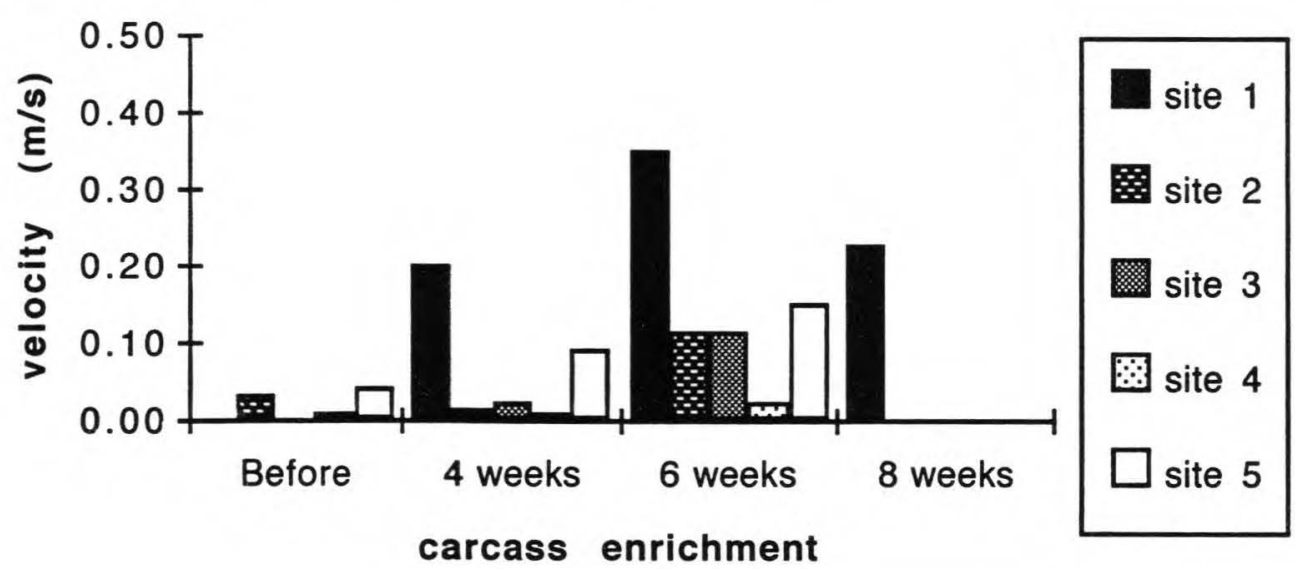

No trends were observed in water chemistry measures at the sites over the experimental period (see Appendix 1).

No tends were observed in the canopy cover over the sample sites (Figure 6)

Figure 6. Percent Overstory Cover.

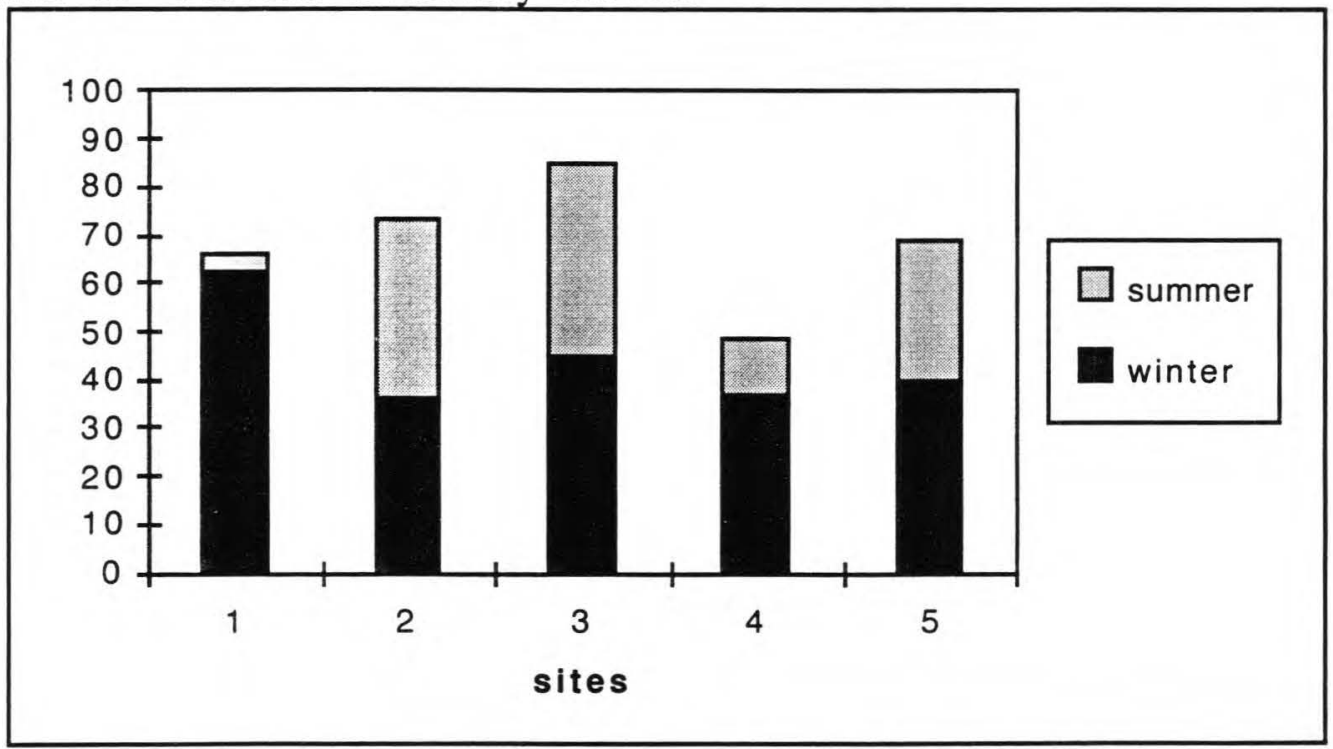




\section{Nutrient-diffusing pot experiment}

The ash-free dry mass and chlorophyll $a$ data for site 1 do not clearly indicate increase with any of the four treatments (Figures 7a and $7 \mathrm{~b}$ ). The nitrogen treatment mean exceeds the confidence interval of the control data in both cases, but this is not supported by the combined nitrogen and phosphorus treatment mean which would also be expected to exceed the confidence interval if nitrogen is limiting periphyton growth.

Data for site 2 indicate a combination of nitrogen and phosphorus limitation (Figures $8 \mathrm{a}$ and $8 \mathrm{~b}$ ).

Data for sites 3, 4 and 5 do not clearly indicate increase with any of the four treatments (Figures 9a, 9b, 10a, 10b, 11a and 11b). Periphyton growth at site 3 may be limited by a combination of nitrogen and phosphorus as indicated by the chlorophyll $a$ mean, but this is not supported by the ash-free dry mass mean.

\section{Coho carcass enrichment experiment}

\section{Biomass measurements}

Data collected six and eight weeks into the treatment period from pots at site 4 were not included in the analysis. All but four replicate pots at this site were lost by the time of the sample collection at four weeks into the treatment period and those four pots were collected at that time. The others had been buried or swept downstream. I replaced enough pots for the final two sampling dates but as the colonization time was much shorter for these, I do not feel that a comparison is valid. 


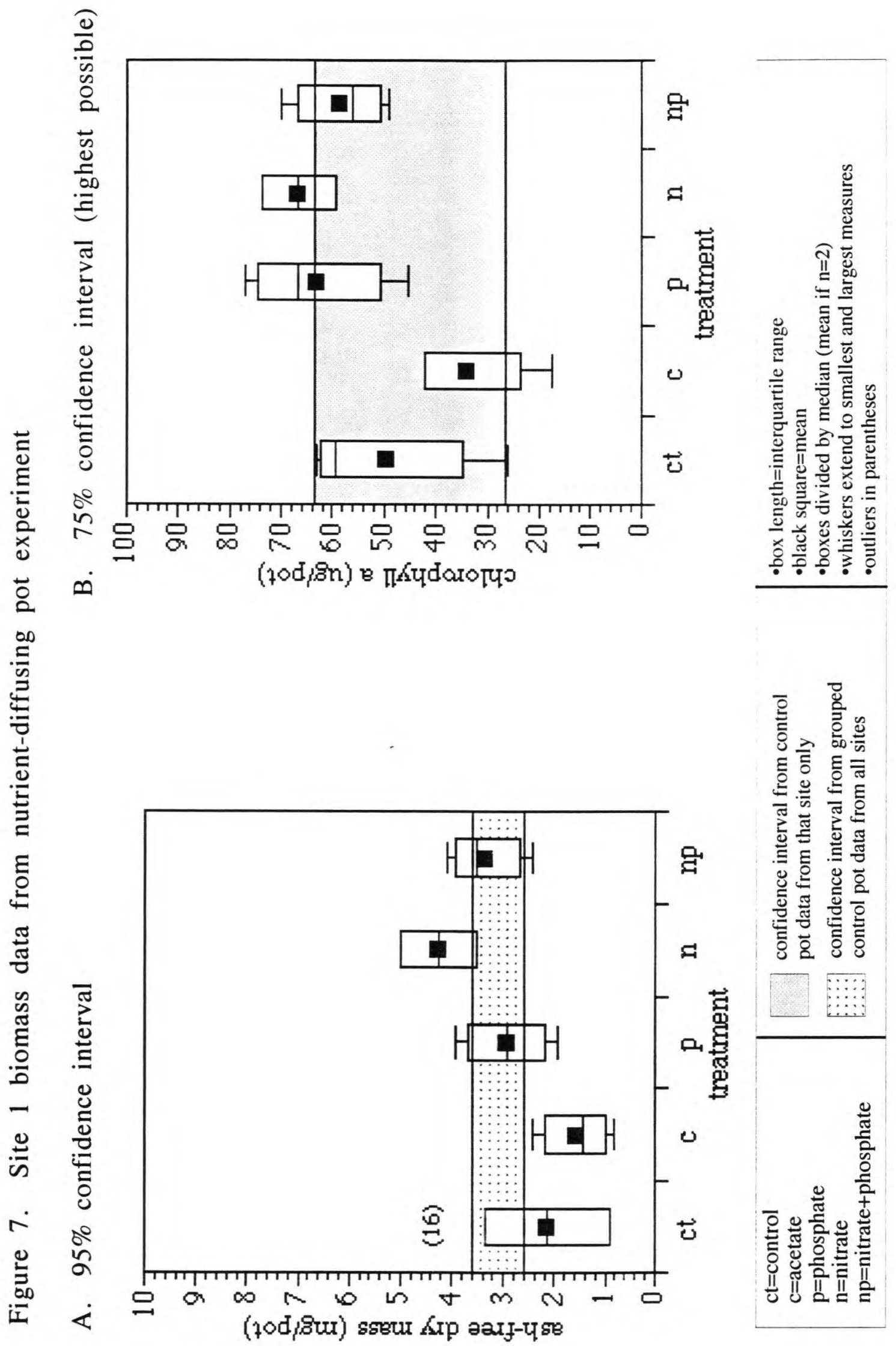




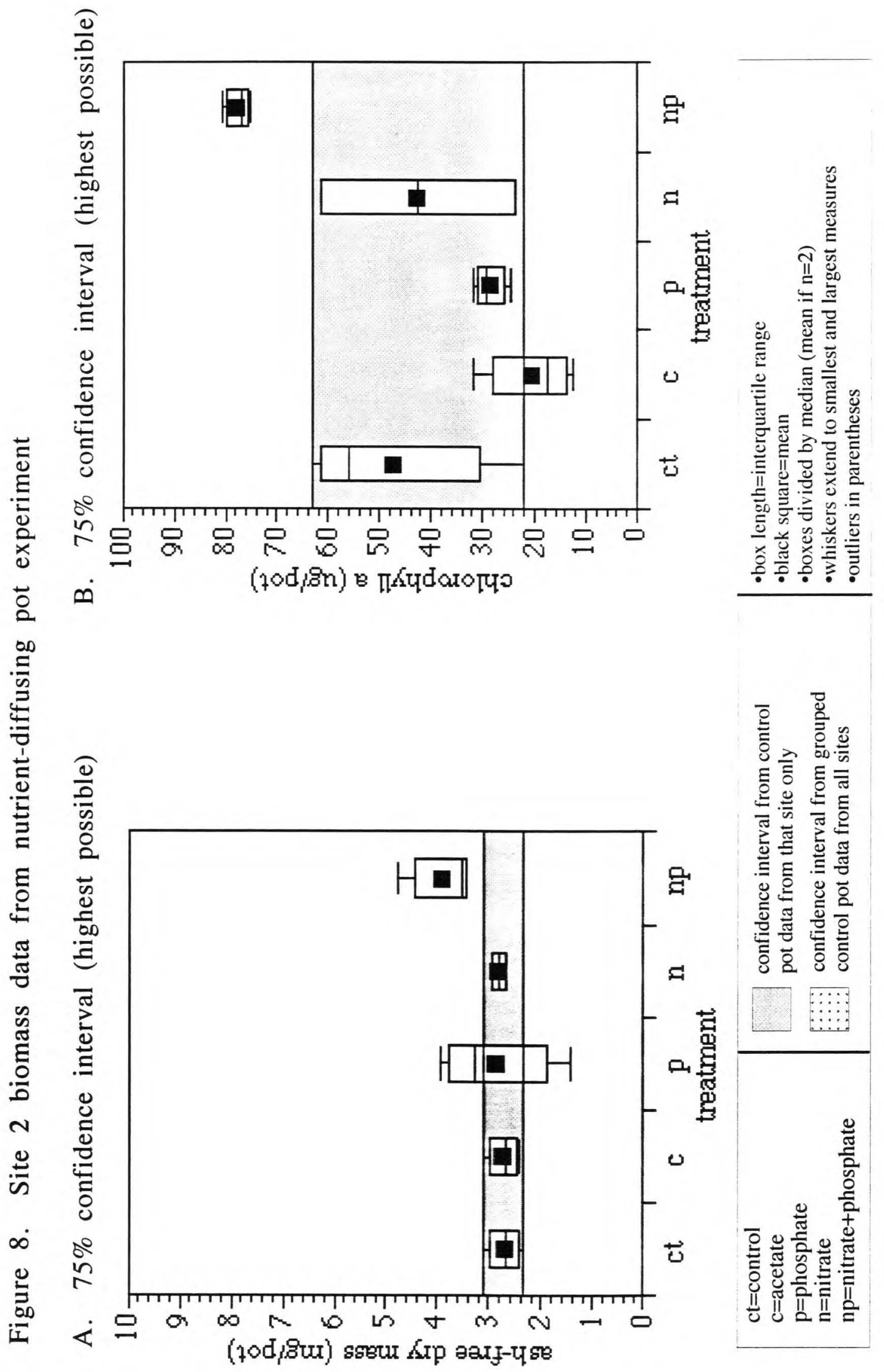




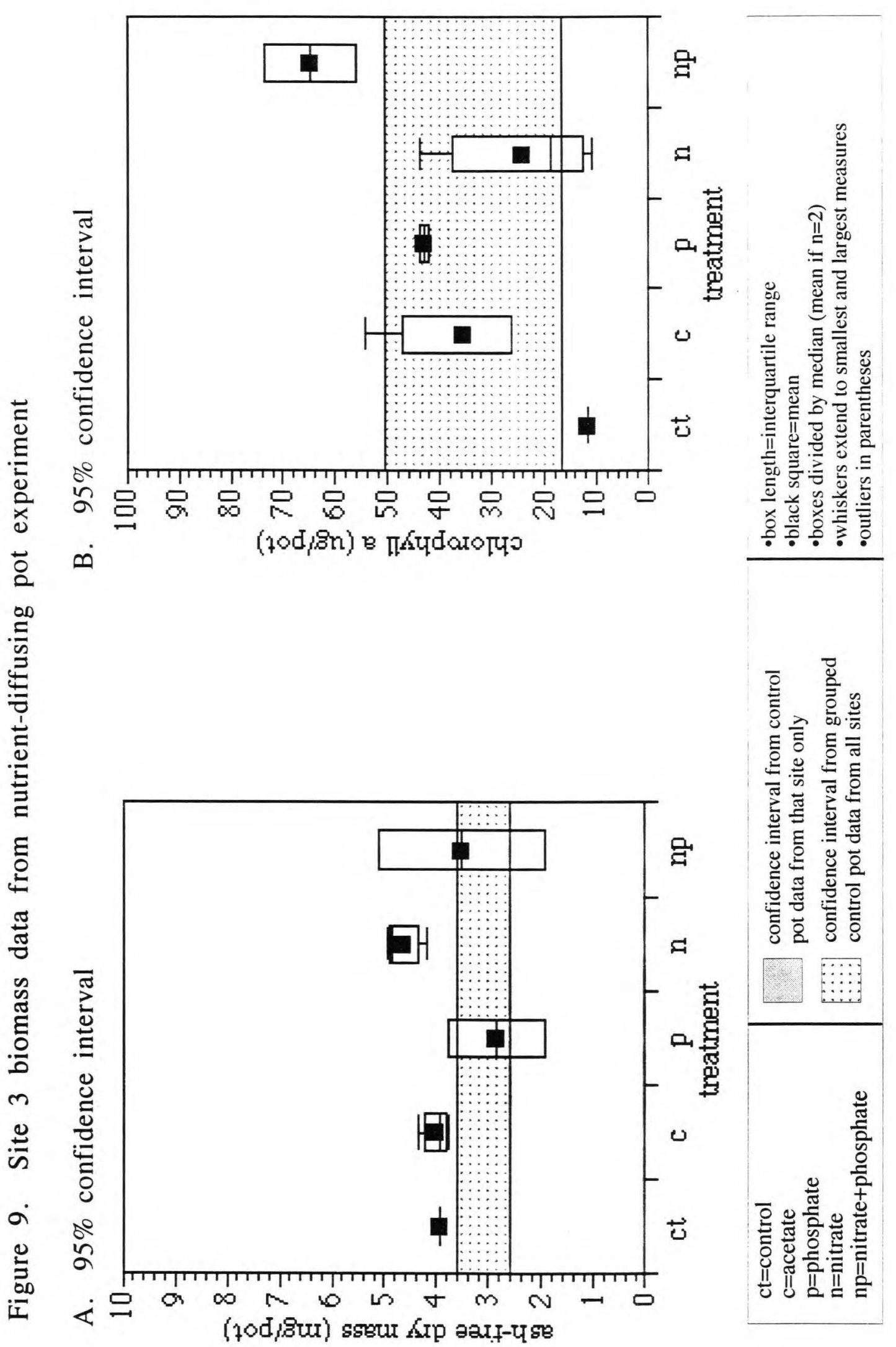




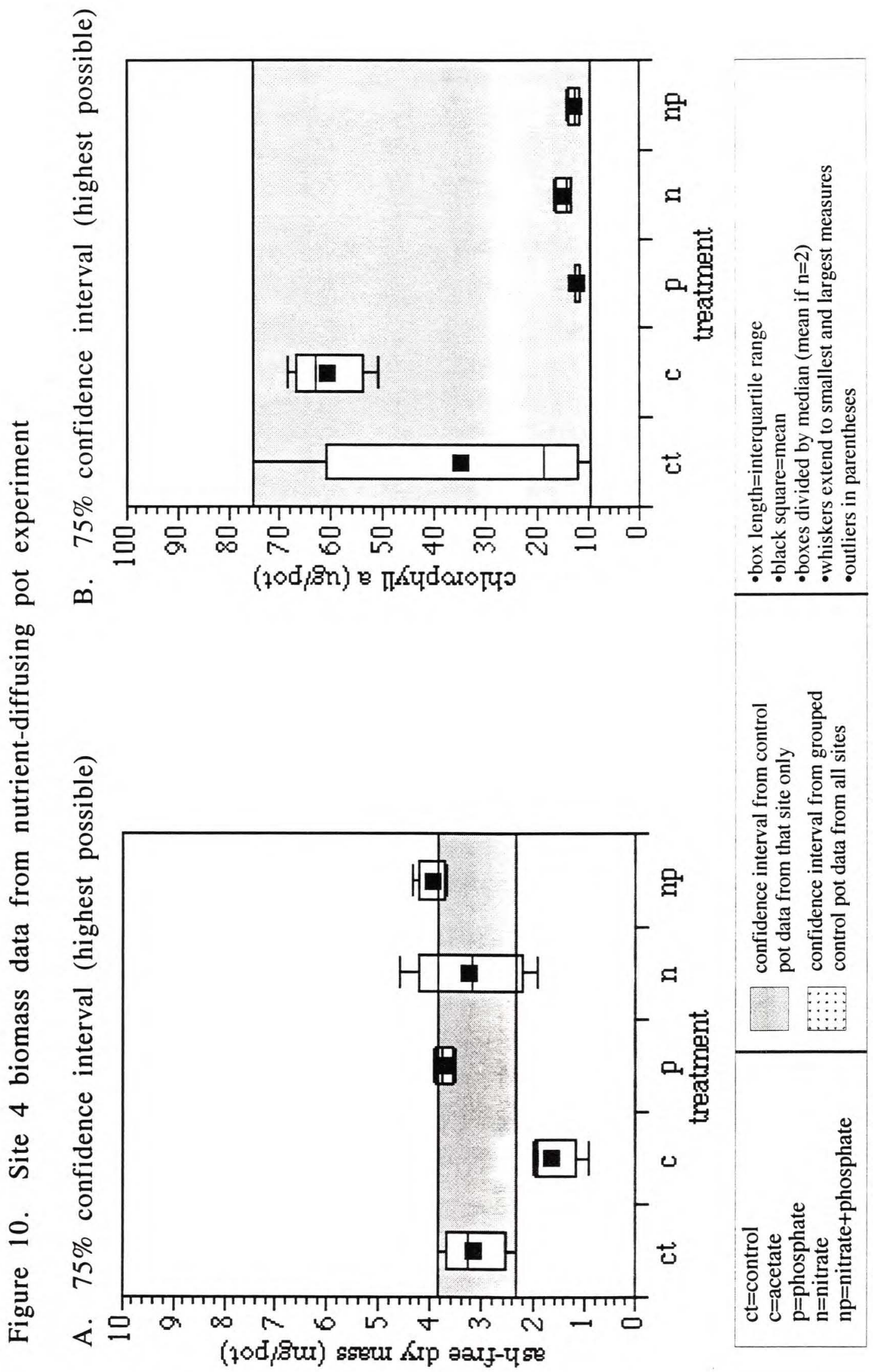




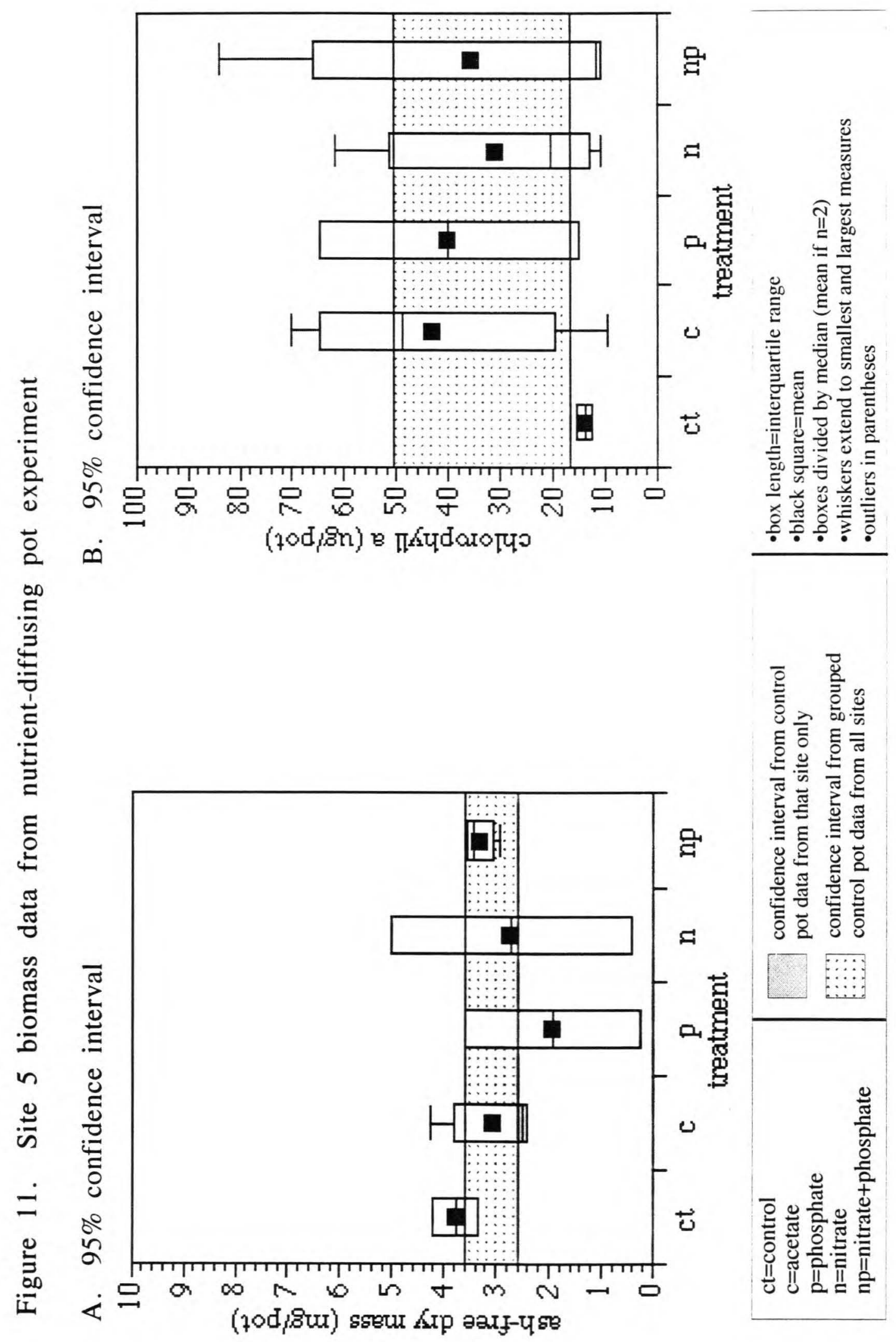


The ash-free dry mass and chlorophyll $a$ data from the five sample sites before the carcasses were placed in the stream do not clearly indicate a difference among the sites (Figures 12a and 12b). Ash-free dry mass means for sites 3 and 5 were above the confidence interval of the reference sites but this was not supported by the chlorophyll $a$ data. In addition, only one replicate could be collected from site 3 , so there were not enough samples to confidently estimate the population mean of these variable measures at that site.

The data from the five sites after four weeks of carcass enrichment indicate that periphyton growth at sites 3 and 5 was greater than at the reference sites (Figures 13a and 13b). The ashfree dry mass mean of site 4 was higher than the confidence interval of the reference site data, but chlorophyll $a$ data from that site do not support the conclusion that the periphyton growth was higher than at the reference sites here as well.

The data from the five sites after six weeks of carcass enrichment indicate that periphyton growth at site 3 was greater than at the reference sites (Figures $14 \mathrm{a}$ and $14 \mathrm{~b}$ ).

The data from the five sites after eight weeks ofcarcass enrichment indicate that periphyton growth at site 3 may still be greater than at the reference sites but, although the chlorophyll $a$ mean is approximately twice those of the reference sites, the ashfree dry mass data do not clearly support this conclusion (Figures $15 \mathrm{a}$ and 15b). 


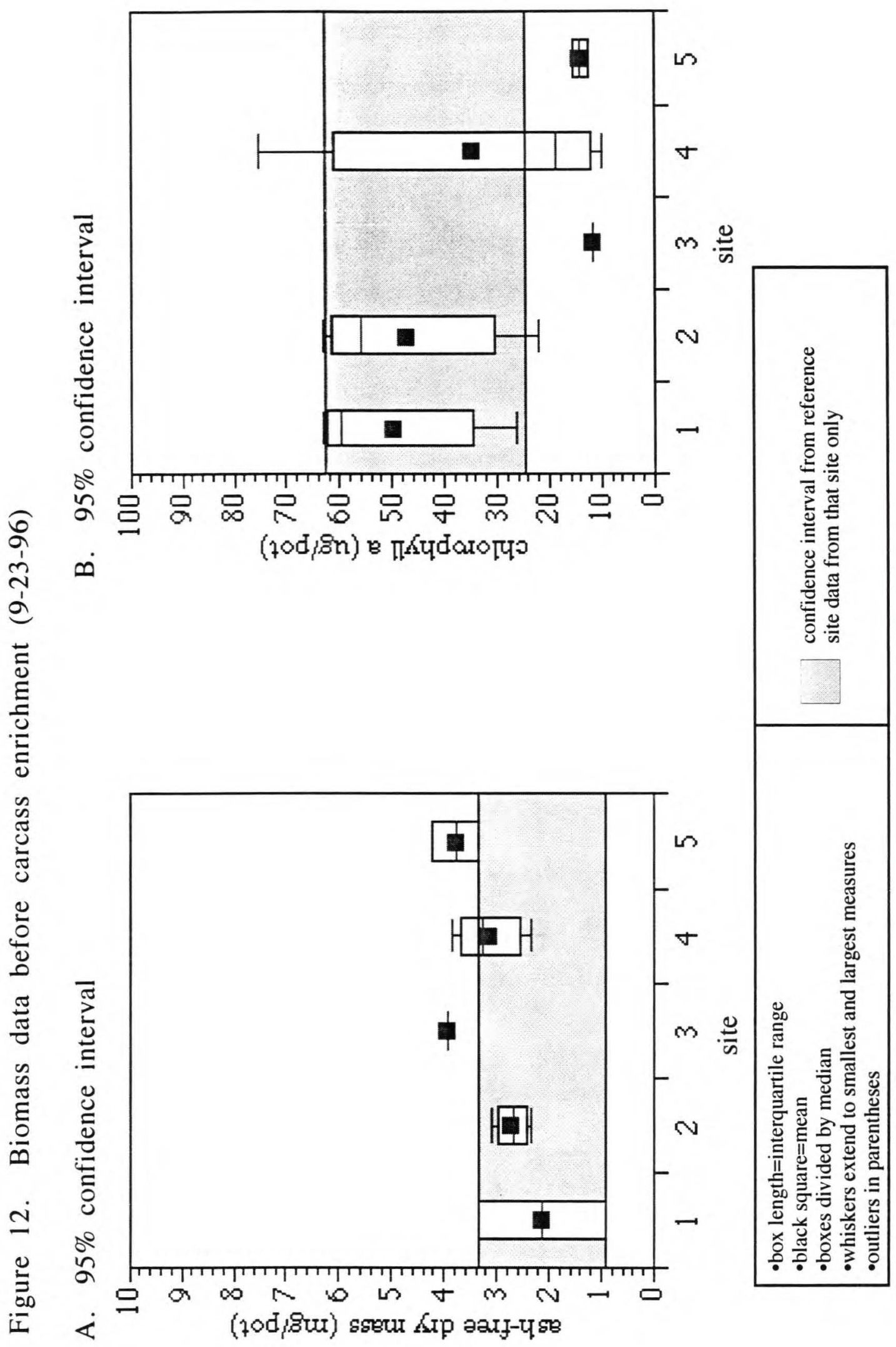




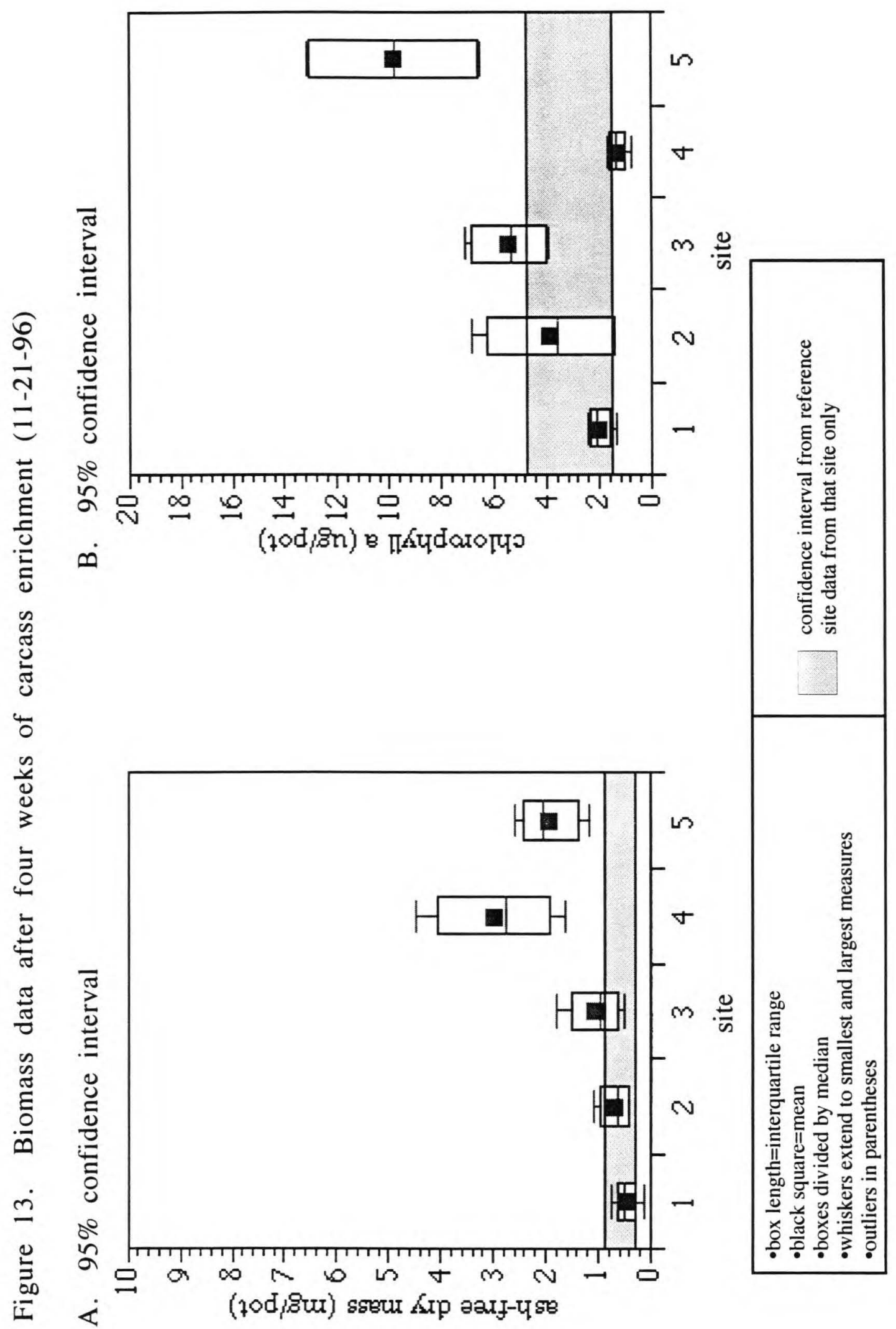




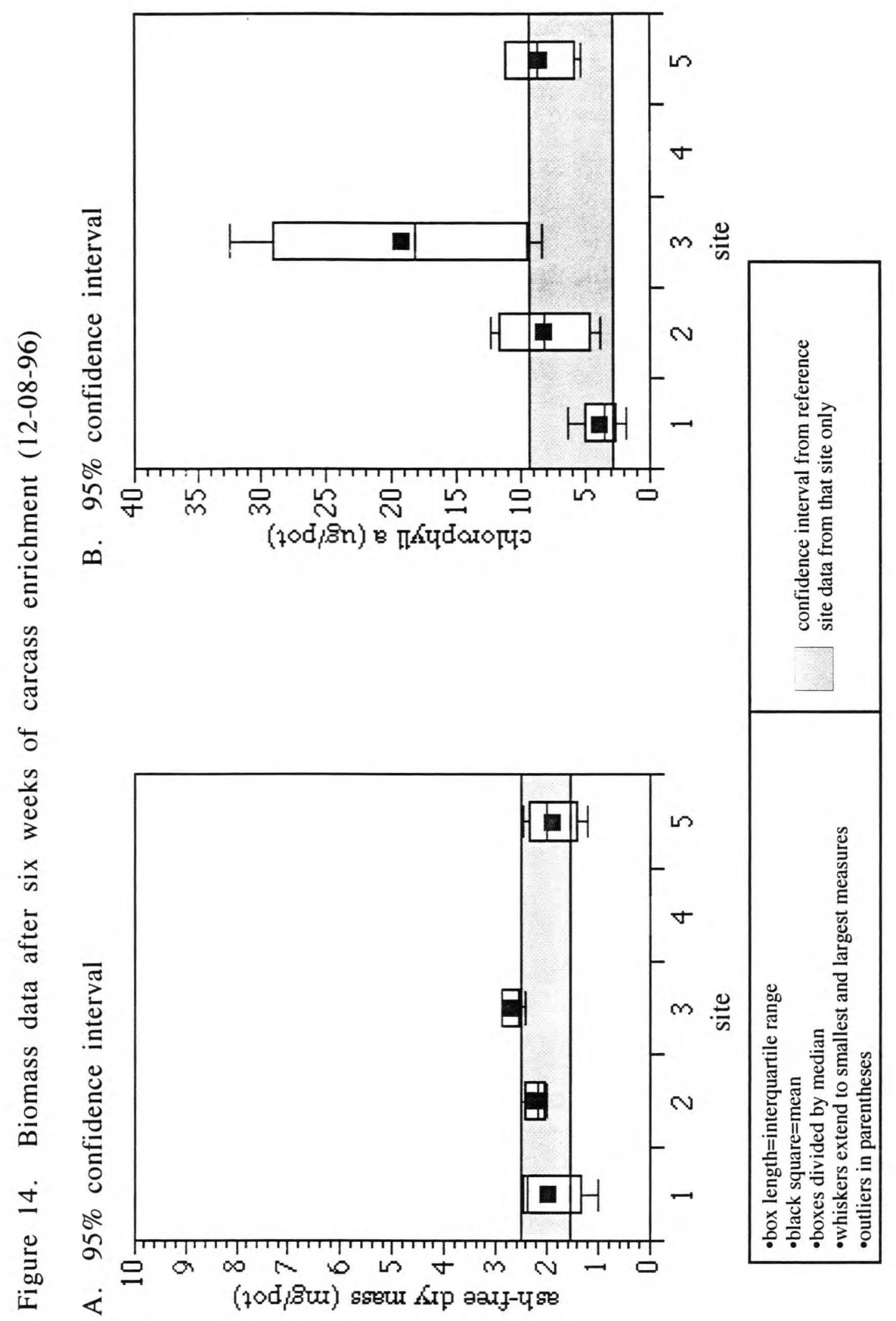




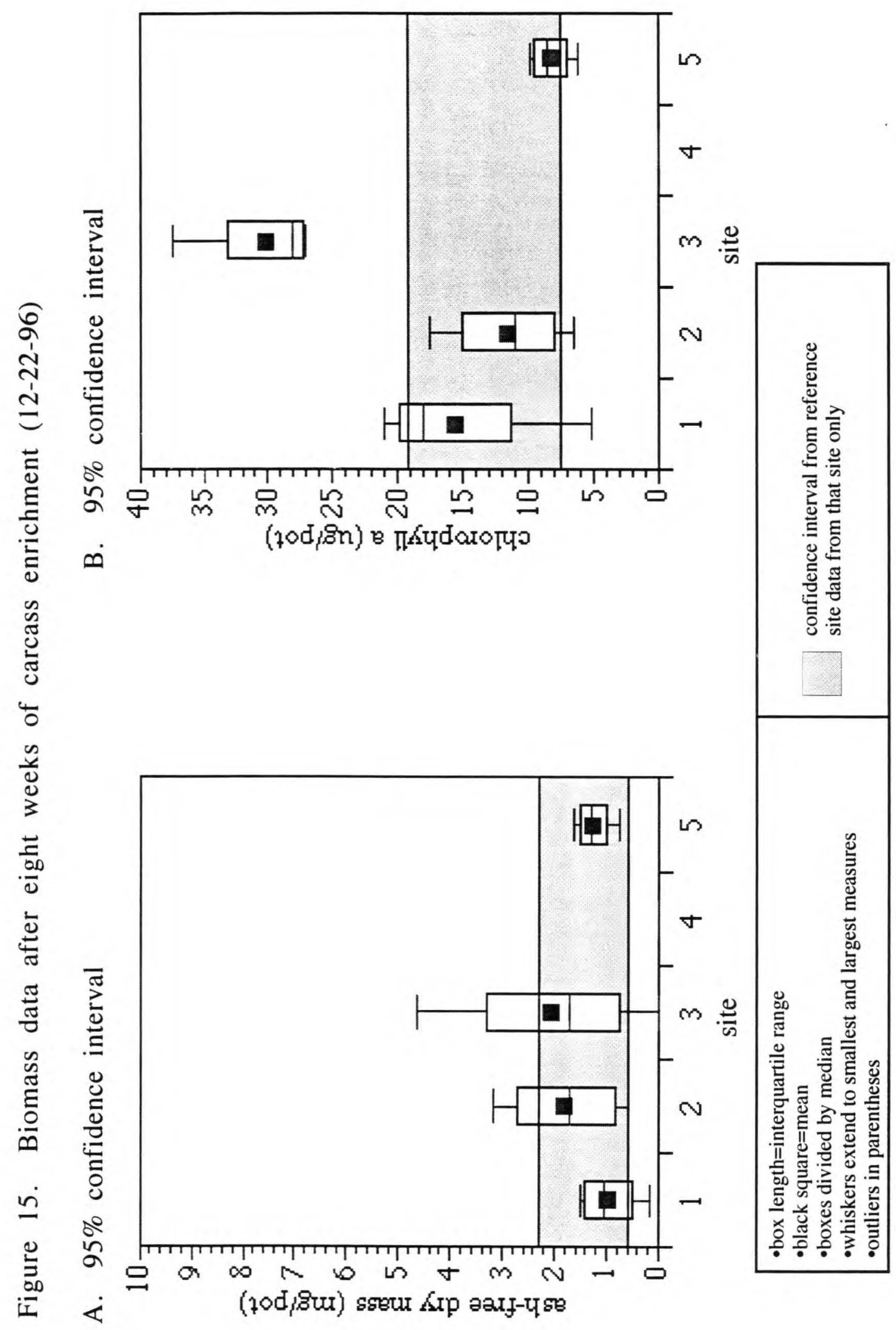




\section{Diatom community composition}

For the sample collection four weeks into the coho carcass enrichment experiment, four dendrograms were constructed from the diatom count data set. The first was made using the Euclidean distance coefficient to calculate resemblance from the original diatom count data (Figure 16). The second also used the Euclidean distance coefficient but it was applied after the data had been standardized (Figure 17). The third was made using the Chord coefficient to calculate resemblance from the original data (Figure 18). The fourth dendrogram was made using the Chord coefficient after the data had been standardized (Figure 19).

Figure 16 groups the sample replicates coherently according to site and treatment level. Only two replicates, one from site 3 and one from site 4, are grouped anomalously. Figure 17 shows almost no grouping of the sample replicates according to site and treatment level. Figure is weakly groups the sample replicates according to site and treatment level. There are two anomalously grouped replicates, both replicates from site 2 , and the replicates from site 1 are not shown to be closely similar to one another. Figure 19 shows almost no grouping of the sample replicates according to site and treatment level. 


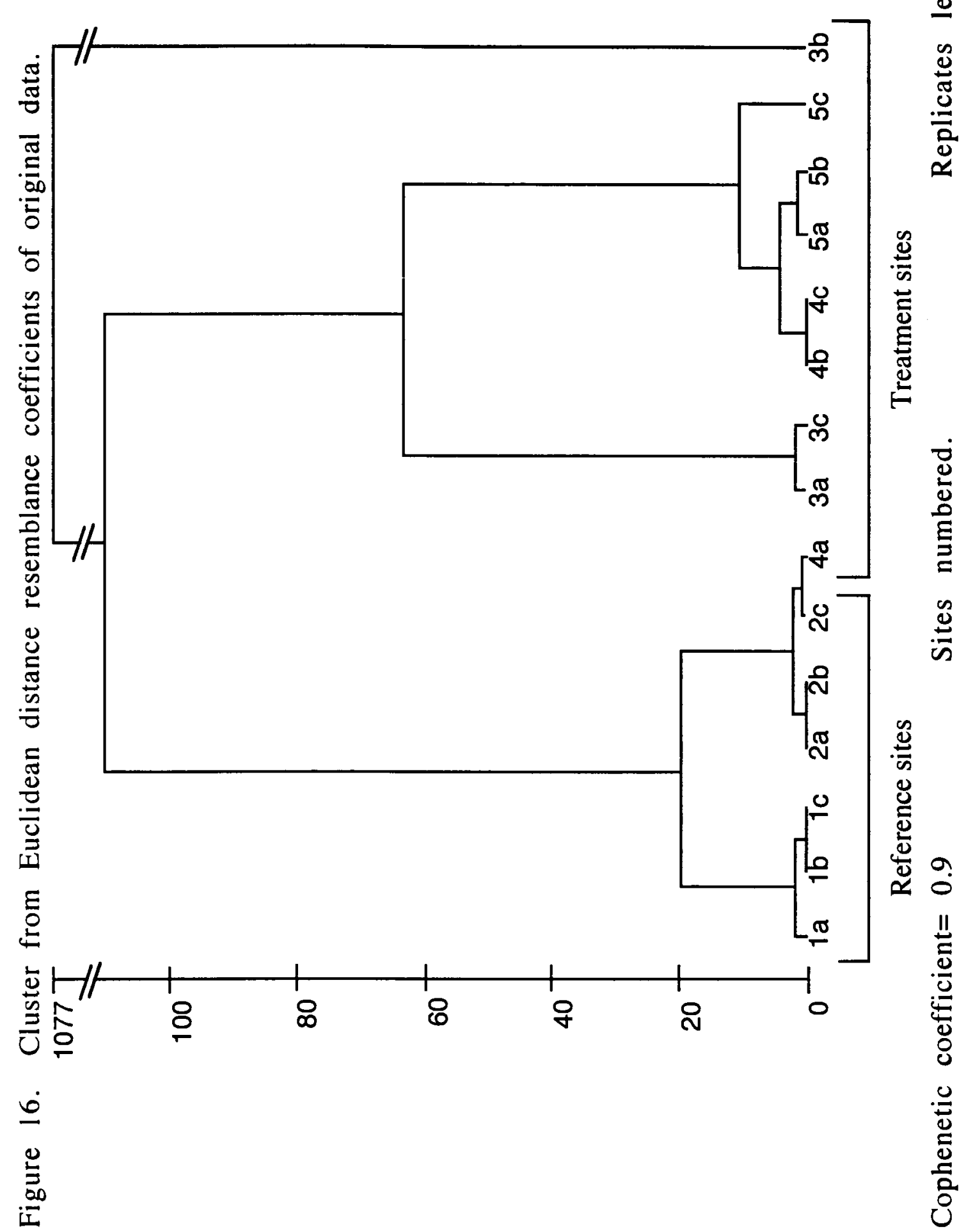




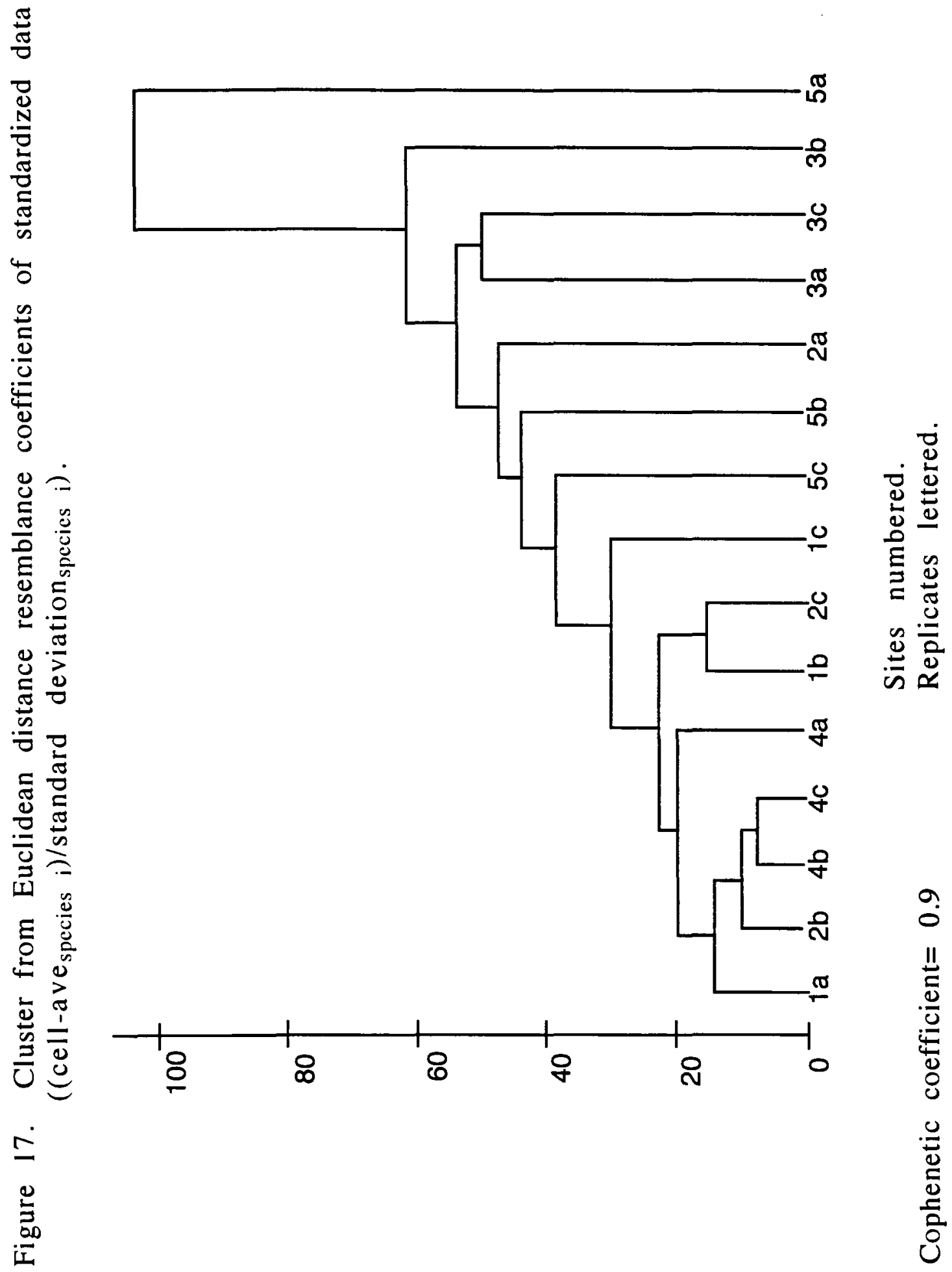




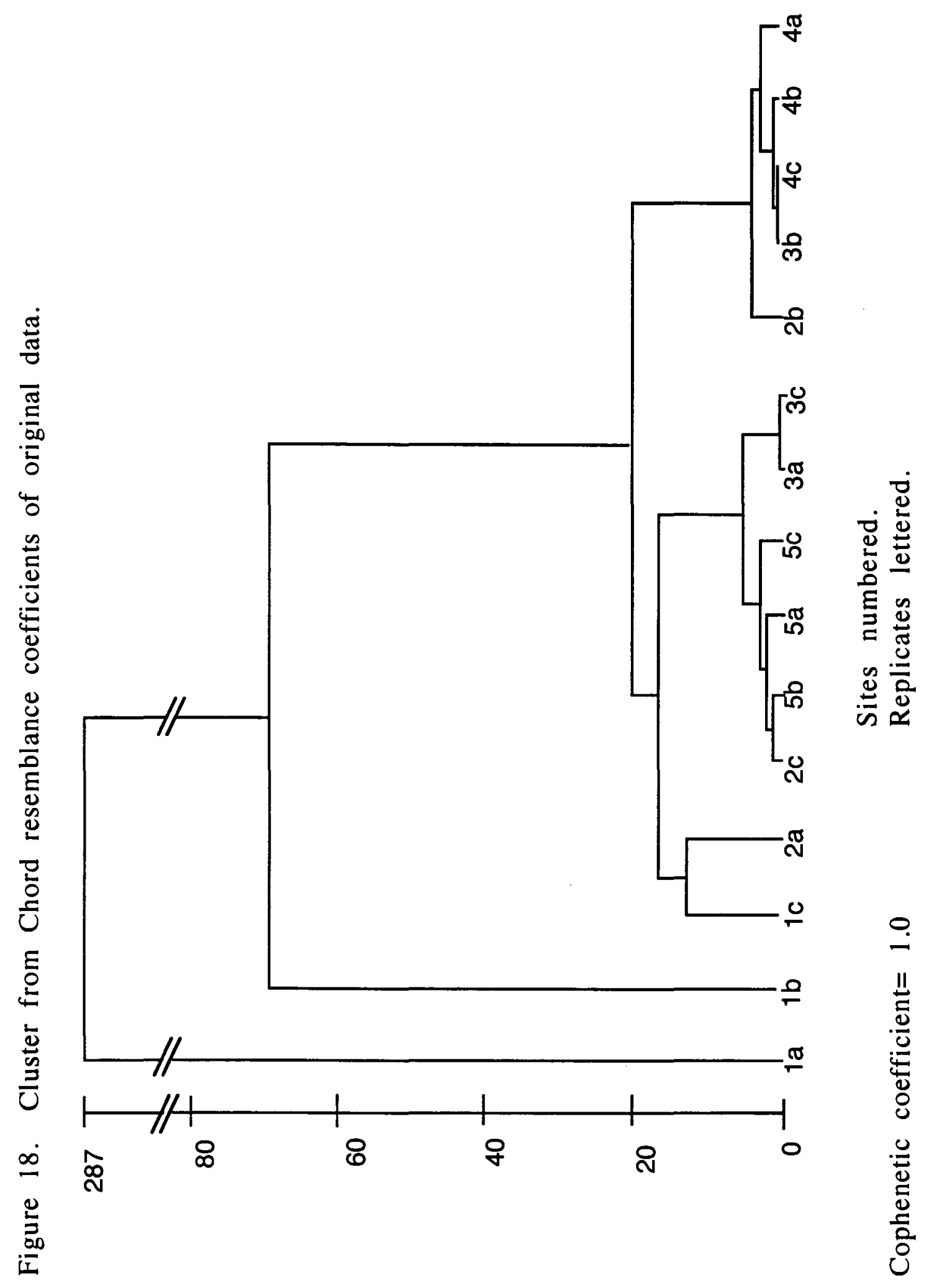




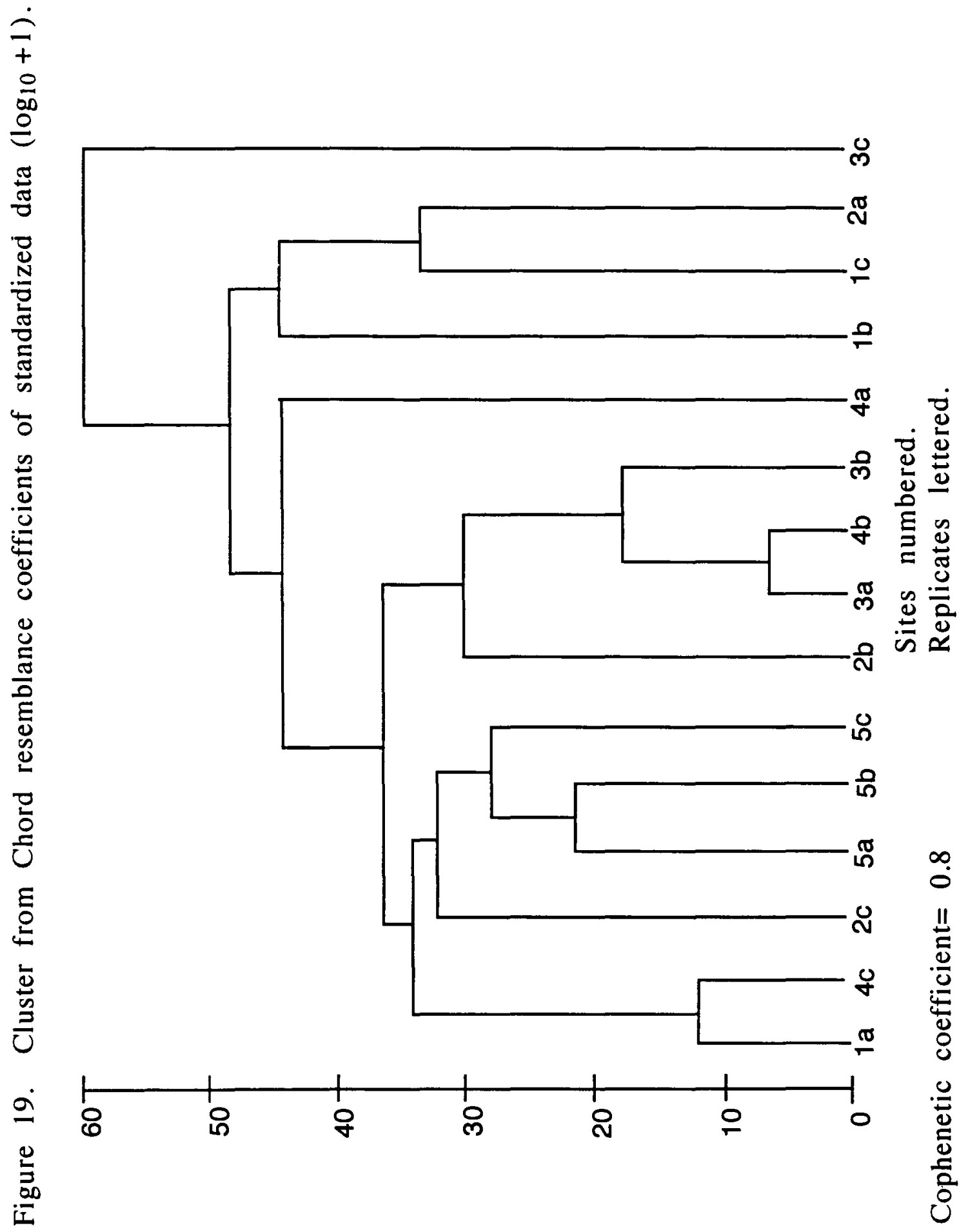




\section{Analysis of nutrients in water}

Four weeks into the coho carcass enrichment experiment, dissolved nitrate-nitrite concentration is more than 3 times higher in the treatment reach than in the reference reach. Total phosphorus at site 3 is higher than in the reference reach (Table 2).

Table 2. Results of water nutrient analysis.

\begin{tabular}{|c|c|c|c|c|c|}
\hline $\begin{array}{l}\text { Time } \\
\text { (RE: } \\
\text { treatment) }\end{array}$ & $\mathbf{T P}$ & TKN & $\mathbf{O P}$ & $\mathrm{NO} 3+\mathrm{NO} 2$ & NH3 \\
\hline before & ND & ND & na & na & na \\
\hline after & $1(.0137)$ & $1(.374)$ & $1(.0058)$ & $1(.009)$ & $1(.007)$ \\
\hline \multirow[t]{4}{*}{ (4 weeks) } & $2(.0128)$ & $2(.740)$ & $2(.0053)$ & $2(.010)$ & $2(.003)$ \\
\hline & $3(.0307)(+.02)$ & $3(.870)$ & $3(.0050)$ & $3(.035)(+.025)$ & $3(.005)$ \\
\hline & $4(.0113)$ & $4(.347)$ & $4(.0045)$ & $4(.031)(+.02)$ & $4(.004)$ \\
\hline & $5(.0121)$ & $5(.268)$ & $5(.0047)$ & $5(.031)(+.02)$ & $5(.003)$ \\
\hline \multirow{3}{*}{$\begin{array}{l}\text { after } \\
\text { (6 weeks) }\end{array}$} & $2(.0129)$ & $2(.233)$ & na & na & na \\
\hline & $3(.0133)$ & $3(.197)$ & & & \\
\hline & $5(.0112)$ & $4(.189)$ & & & \\
\hline \multicolumn{6}{|c|}{$\begin{array}{l}\text { TP= total phosphorus }(\mathrm{mg} / \mathrm{L}) \\
\mathrm{TKN}=\text { total Kjeldahl nitrogen }(\mathrm{mg} / \mathrm{L}) \\
\mathrm{OP}=\text { orthophosphate (filterable or "dissolved") }(\mathrm{mg} / \mathrm{L}) \\
\mathrm{NO} 3+\mathrm{NO}=\text { "dissolved" nitrates and nitrites combined }(\mathrm{mg} / \mathrm{L}) \\
\mathrm{NH} 3=\text { "dissolved" ammonia }(\mathrm{mg} / \mathrm{L}) \\
\text { na= not applicable } \\
\mathrm{ND}=\text { not detectable above Coffey Lab's limits }(\mathrm{TP}=0.05, \mathrm{TKN}=0.2)\end{array}$} \\
\hline
\end{tabular}

\section{DISCUSSION}

Data from all the sites on the "before treatment" sampling date show that the sites were initially similar and data over all sampling dates from sites 1 and 2 show that, in the absence of carcasses, temporal trends are similar for these sites. This suggests that background trends of change remain constant among the sites 
throughout the study, however this cannot be tested without data on the background trends at sites 3,4 and 5 (i.e., more "before treatment" sample times).

Nevertheless, it remains that the sites were initially similar as described by measurements of ash-free dry mass and chlorophyll $a$ concentration and that later, coinciding with the addition of coho carcasses, some treatment sites differed from the reference sites. There are three major factors with the potential to effect a difference in the timecourse between the reference and treatment sites. The first possibility is that different communities populate the sites and that these communities were by chance similar at first. If so, it would be no surprise that the different communities would have different temporal trajectories reflected in differences in biomass or chlorophyll concentration. However, I do not believe that a difference in community make-up is what is responsible for the increase in biomass and chlorophyll $a$ concentration in the treatment sites. The results of different clustering methods of the diatom count data collected after the coho carcasses had been placed in the stream show that when the samples are grouped using methods that decrease sensitivity to size displacement among samples (i.e., when the data are standardized), the replicates are not grouped according to site (Figures 17 and 19). This suggests that diatom communities at each site are not sufficiently different from one another for replicates from a single site to be grouped together. Even when the samples are grouped using the method that avoids weighting common species (i.e., using the Chord resemblance 
coefficient), the samples are only weakly grouped according to site (Figure 18). This suggests that even when less common species are given more weight, the sites are not distinctly different from one another in terms of species composition. The samples are grouped most coherently by the method that is sensitive to size and common species (i.e., using the Euclidean distance resemblance coefficient on non-standardized data) (Figure 16). The results of these clustering methods suggest that the communities at each site are similar except in their sizes so a differing timecourse in community development due to different community compositions is probably not the explanation for the differences between the reference and treatment sites.

The second major factor with the potential to effect a difference in the timecourse between the reference and treatment sites is an event occuring upstream of the treatment sites but downstream of the reference sites. Such an event, affecting only the treatment sites, would have to be large such as a tree-fall or a tributary. I walked down the reach between the last reference site and the first treatment site approximately once every two weeks during the study and observed no such events. The study reach was also investigated by Coley Powers to study carcass movement. He reported no such events. Moreover, there are no corroborating trends between the reference and treatment sites from the data on canopy cover, water chemistry and depth. The higher velocity at site 1 during the enrichment period did not result in differences in ash-free dry mass and chlorophyll $a$ concentration between 
reference sites $I$ and 2 , so I do not believe this difference to be a confounding factor.

The final major factor with the potential to effect a difference in the timecourse between the reference and treatment sites is of course the treatment itself. The increase in ash-free dry mass and chlorophyll $a$ concentration in the treatment reach may be a response to the increase in dissolved nutrients resulting from the decomposition of the coho carcasses. There are reasons to believe this is the case.

One reason is that the timing of the change between the reference sites and treatment sites coincides with the carcass enrichment.

Another reason is the results of the nutrient analysis of the water sampled during the enrichment period. There is an increase in dissolved nitrate-nitrite concentration in the water of the treatment reach. There is also an increase of total phosphorus (particulate plus dissolved) in the water at site 3 that is not found at any of the other sites. There was no increase in total nitrogen (particulate plus dissolved), dissolved phosphorus or ammonium in the water of the treatment reach.

Decomposing carcasses certainly release nutrients as shown by the studies cited in the introduction of this paper tracing the pathway of MDN from the adult salmon throughout stream ecosystems. These nutrients will be in the form of particulate organic matter produced by physical abrasion of the carcasses and sloppy eating by macroinvertebrates and fish or in the form of 
dissolved organic nutrients produced as metabolic waste or in the form of mineralized inorganic nutrients produced by bacterial action on all of the above. The nutrients released from the carcasses may be removed from the water by consumption or adsorbing to some surface such as a cobble or the polysaccharide matrix of the benthic microbial community (Allan 1995). The nutrients are thereby temporarily incorporated into the biota or streambed before being excreted or desorbed to continue transport downstream where they may again be removed and recycled (Webster and Patten's nutrient "spiraling" concept 1979). If the nutrients-other than the nitrates-nitrites and, initially, total phosphorus-are not in the water column during carcass decomposition, they must be either locked up in the biota or adsorbed to some surface. Either way, the nutrients are available to the periphyton community which can "mine" from surfaces or absorb dissolved nutrients released by the biota through excretion of soluble wastes or bacterial remineralization.

\section{Weaknesses and anomalies in the study}

This study was performed in only one stream using only one treatment reach. This has resulted in an absence of true replication and therefore weakens any conclusions that might be drawn from the study (Hurlbert 1984). A modified BACI design was used to overcome this deficiency but the BACI design itself was inadequately implemented using only one "before treatment" sample rather than multiple "before treatment" samples as advised 
by Stewart-Oaten et al. (1986). For this reason, background temporal trends cannot be compared among the sites in order to determine with certainty if an additional treatment effect occurs. The lack of independence of the downstream sites from the upstream sites means that any event affecting measurements at one site has the potential to affect downstream measurements. This problem is made more serious by the lack of treatment replication. Replication would reduce the importance of the effect of random events on any particular measurement in the data sets.

Other than the apparent stimulation of periphyton growth by the nitrogen plus phosphorus treatment at site 2 , the nutrientdiffusing pot experiment found no clear evidence of nutrient limitation before the coho carcass enrichment. There are five interpretations of this result: One, that the periphyton community is not limited by those nutrients at that time; two, that the low number of replicates collected resulted in data with a large amount of variance obscuring any differences present; three, that the nutrient concentrations used were not high enough; four, that the pots were not far enough apart to prevent cross-contamination of the diffusing nutrients; or five, that the pots were left out too long and the periphyton communities had already reached climax (due to current, space or etc. restrictions) by the time they were removed from the pots for analysis. If the first is the case, that does not preclude a shift to nutrient limitation during another season. The nutrient-diffusing pot experiment was performed in late summer during low flow and high irradiation days while the 
carcass enrichment experiment was performed during the fall and early winter during high flow (which dilutes nutrients) and low irradiation days (though the canopy had been opened somewhat by leaf-fall).

While the ash-free dry mass and chlorophyll data from the coho carcass enrichment study both show no differences in the temporal trends of the references sites, there is some disagreement on the location and timing of the treatment effect. Four weeks into the enrichment period, site 4 shows an increase in biomass but no significant change in chlorophyll $a$. I have no certain explanation for this, but it should be noted that at that time when I collected the four replicate pots from this site, all eleven of the other pots at this site had been buried in the shifting gravel or swept away suggesting that even the four remaining pots which I collected might have had their algae scoured away by the active sediments of that site. The ash-free dry mass measures here may have been high due to sediment deposition on the pots.

The chlorophyll $a$ data alone shows a spike that occurs at site 3 at eight weeks into the enrichment period. The only insight I can offer is my observation of a debris-jam approximately $15 \mathrm{~m}$ upstream on which four to five coho carcasses had been caught underwater away from the reach of predators that remove many carcasses from the stream. The carcasses remained in the debrisjam through at least the sixth week of the enrichment period. Reduced irradiance may cause an increase in chlorophyll without a large increase in biomass as the algae divert their resources to 
increasing the surface area of their light-harvesting units to capture more of the less available light but the trends in canopy cover over the sites do not support this explanation. Alternatively, any increase in nutrients may increase the concentration of chlorophyll in the periphyton with the subsequent increase in biomass from the increased primary productivity possibly being consumed by grazing macroinvertebrates. This hypothesis cannot be tested until the macroinvertebrate data analysis is completed by the USFS.

\section{Cautious conclusion}

The evidence is that nutrients released by the decomposition of the coho carcasses are available to the periphyton community of the treatment reach; that primary production is stimulated in the treatment reach after the carcasses are introduced; and that, other than the carcasses, no factors were observed that have the potential to cause differences in primary production between the reference and treatment sites. This evidence supports the conclusion that decomposition of the coho carcasses stimulated algal growth in the treatment reach.

\section{Additional considerations}

The goal of this study was to determine whether the algae in Still Creek are stimulated by the nutrients released from decomposing adult salmonid carcasses. This question must be answered in order to determine if the algae of Still Creek and similar streams in the area can function as an intermediary and 
facilitator in the nutrient transfer between adult and juvenile salmonids. To more fully understand this nutrient transfer process, other participants and their roles must be identified. We must determine if the greater primary production supports greater secondary production. USFS personnel collected macroinvertebrate samples in the course of this study and when the analysis is complete, increases in the proportions of grazing insects in the treatment reach would be evidence supporting the transfer of the MDN from the algae to the invertebrate community. Using the same macroinvertebrate data, we will also determine whether the carcasses stimulate secondary production via direct consumption as has been found in other studies. Increases in the proportions of scavenging insects in the treatment reach would be evidence that this pathway is available for the transfer of the MDN from adult to juvenile salmonids. Finally, we hope to determine if any increased production at these lower trophic levels actually makes its way to the juveniles. This spring, escapement will be measured at a smolt trap approximately two river-miles downstream from the treatment reach. The results will be compared to escapement data accumulated over the past 10 years for evidence of an increase. 


\section{References}

Allan, J. D. 1995. Stream Ecology: Structure and function of running waters. Chapman and Hall: New York. 388pp.

American Public Health Association, American Water Works Association, and Water Environment Federation. 1992. Standard Methods for the Examination of Water andWastewater, 18th ed. A. E. Greenberg, L.S. Clesceri, A. D. Eaton (eds). American Public Health Association, Washington DC.

Axler, R. P. and C. J. Owen. 1994. Measuring chlorophyll and pheophytin: whom should you believe? Lake and Reservoir Management. 8 (2): 143-151.

Barnese, L. E. and C. L. Schelske. 1994. Effects of nitrogen, phosphorus and carbon enrichment on planktonic and periphytic algae in a softwater, oligotrophic lake in Florida, USA. Hydrobiologia. 227: 159-170.

Bilby, R. E., B. R. Fransen and P. A. Bisson. 1993. Incorporation of nitrogen and carbon from spawning coho salmon into the trophic system of small streams: Evidence from stable isotopes. Environmental Forestry Research, Weyerhaeuser Co., Tacoma, WA.

Borchardt, M. A. 1996. Nutrients. In: Algal Ecology: Freshwater benthic ecosystems. R. J. Stevenson, M. L. Bothwell and R. L Lowe, eds. Academic Press: San Diego. 753pp.

Brower, J. E., J. H. Zar and C. N. von Ende. 1990. Feild and Laoratory Methods for General Ecology. 3rd ed. Brown Publishers: Dubuque. 237.

Cederholm, C. J., D. B. Houston, D. L. Cole and W. J. Scarlett. 1989. Fate of coho salmon (Oncorhynchus kisutch) carcasses in spawning streams. Canadian Journal of Fisheries and Aquatic Sciences. 46: 1347-1355:

Eggers, D. M. and D. E. Rogers. 1987. The cycle of runs of sockeye salmon (Oncorhynchus nerka) to the Kvichak River, Bristol 
Bay: cyclic dominance or depensatory fishing? In H. D. Smith, L. Margolis, and C. C. Wood [ed.] Sockeye salmon (Oncorhynchus nerka) population biology and future management. Canadian Special Publication on Fisheries and Aquatic Sciences. 96: 343-366.

Fairchild, G. W. and R. L. Lowe. 1984. Artificial substrates which release nutrients: Effects on periphyton and invertebrate succession. Hydrobiologia. 114: 29-37.

Fisher-Wold, A. K. and A. E. Hershey. 1995. The effects of salmon carcass decomposition on diatom diversity in a stream ecosystem. Abstract in 43rd Annual Meeting Program Issue Keystone Resort, Colorado. Bulletin of the North American Benthological Society. vol 12.

Franklin, J. F. and C. T. Dyrness. 1988. Natural Vegetation of Oregon and Washington. OSU press: Corvalis, Oregon. $452 \mathrm{pp}$.

Hitchcock, C. L. and A. Cronquist. 1973. Flora of the Pacific Northwest. University of Washington Press: Seattle, WA. $730 \mathrm{pp}$.

Hollander, M. and D. A. Wolfe. 1973. Nonparametric Statistical Methods. Wiley and Sons: New York. 503 pp.

Hurlbert, S. J. 1984. Pseudoreplication and the design of ecological field experiments. Ecological Monographs. 54: 187-211.

Kassoy, Erin. The Impact of Global Climate: El Niño/Southern Oscillation. Stanford Users' Web Server: November 1996. http://www-leland.stanford.edu/ ekassoy/el_nino.html. December 1996.

Kline, T. C., J. J. Goering, O. A. Mathisen, P. H. Poe and P. L. Parker. 1990. Recycling of elements transported upstream by runs of Pacific salmon: $\delta^{15} \mathrm{~N}$ and $\delta^{13} \mathrm{C}$ evidence in Sashin Creek, southeastern Alaska. Canadian Journal of Fisheries and Aquatic Sciences. 47: 136-144. 
Kline, T. C., J. J. Goering, O. A. Mathisen, P. H. Poe, P. L. Parker and R. S. Scalan. 1993. Recycling of elements transported upstream by runs of Pacific salmon: $\delta^{15} \mathrm{~N}$ and $\delta^{13} \mathrm{C}$ Evidence in the Kvichak River watershed, Bristol Bay, Southwestern Alaska. Canadian Journal of Fisheries and Aquatic Sciences. 50: 2350-2365.

Kruskal, W. H. and W. A. Wallis. 1952. Use of ranks in one-criterion variance analysis. Journal of the American Statistical Association. 47: 583-621.

Lamberti, G. A. 1996. The role of periphyton in benthic food webs. In: Algal Ecology: Freshwater benthic ecosystems. R. J. Stevenson, M. L. Bothwell and R. L Lowe, eds. Academic Press: San Diego. 753pp.

Ludwig, J. A. and J. F. Reynolds. 1988. Statistical Ecology : a primer on methods and computing. Wiley: New York. 337pp.

Marker, A. F. H. 1972. The use of acetone and methanol is the estimation of chlorophyll in the presence of phaeophytin. Freshwater Biology. 2: 361-385.

Marks, J. C. and R. L. Lowe. 1992. Interactive effects of nutrient availability and light levels on the periphyton composition of a large oligotrophic lake. Canadian Journal of Fisheries and Aquatic Sciences. 50: 1270-1278.

Michael Jr., J. H. 1995. Enhancement effects of spawning pink salmon on stream rearing juvenile coho salmon: managing one resource to benefit another. Northwest Science. 69(3): $228-233$.

Morin, A. and A. Cattaneo. 1992. Factors affecting sampling variablility of freshwater periphyton and the power of periphyton studies. Canadian Journal of Fisheries and Aquatic Sciences. 49: 1695-1703.

Mulholland, P. J. 1996. Role in nutrient cycling in streams. In: Algal Ecology: Freshwater benthic ecosystems. R. J. 
Stevenson, M. L. Bothwell and R. L Lowe, eds. Academic Press: San Diego. 753pp.

Nehlsen, W., J. E. Williams and J. A. Lichatowich. 1991. Pacific salmon at the crossroads: stocks at risk from California, Oregon, Idaho and Washington. Fisheries. 16:4-21.

Nielsen, J. L. 1992. Microhabitat-specific foraging behavior diet and growth of juvenile coho salmon. Transactions of the American Fisheries Society. 121 (5): 617-634.

Patrick, R. and C. W. Reimer. 1966. The Diatoms of the United States. Vol. I. Sutter House: Lititz, PA.

Patrick, R. and C. W. Reimer. 1975. The Diatoms of the United States. Vol. II. Sutter House: Lititz, PA.

Pielou, E. C. 1974. Population and Community Ecology. Gordon and Breach Science Publishers: New York. 424pp.

Pielou, E. C. 1977. Mathematical Ecology. Wiley and Sons: New York. 385pp.

Powers, C. T. 1997. Still Creek Coho Enrichment Project: Tracking of distributed carcasses. Draft submitted to Zigzag Ranger District, Mt. Hood National Forest, US Department of Agriculture Forest Service.

Rand, P. S., C. A. S. Hall, W. H. McDowell, N. H. Ringler and J. G. Kennen. 1992. Factors limiting primary productivity in Lake Ontario tributaries receiving salmon migrations. Canadian Journal of Fisheries and Aquatic Sciences. 49: 2377-2385.

Richey, J. E., M. A. Perkins and C. R. Goldman. 1975. Effects of kokanee salmon (Oncorhynchus nerka) decomposition on the ecology of a subalpine steam. Journal of Fisheries Research Board of Canada. 32: 817-820.

Rieman, B. E., R. C. Beamesderfer, S. Vigg and T. P. Poe. 1991. Estimated loss of juvenile salmonids to predation by northern squawfish, walleys and smallmouth bass in John Day 
Reservior, Columbia River, USA. Transactions of the American Fisheries Society. 120 (4): 448-458.

Romesburg, H. C. 1984. Cluster Analysis for Researchers. Lifetime Learning Publications: Belmont, CA. 334pp.

Schuldt, J. A. and A. E. Hershey. 1995. Effect of salmon carcass decomposition on Lake Superior tributary streams. Journal of the North American Benthological Society. 14(2): 259-268.

Sokal, R. R. and F. J. Rohlf. 1995. Biometry: The Principles and Practice of Statistics in Biological Research. Freeman and Company: New York. 887pp.

Stewart-Oaten, A., W. M. Murdoch and K. R. Parker. 1986. Environmental impact assessment: "pseudoreplication" in time? Ecology. 67: 929-940.

Underwood. 1992. Beyond BACI: the detection of environmental impacts on populations in the real, but variable, world. Journal of Experimental Marine Biology and Ecology. 161: $145-178$.

Underwood, A. J. 1994. On beyond BACI: Sampling designs that might reliably detect environmental disturbances. Ecological Applications. 4: 3-15.

United Nations. Food and Agriculture Organization. Fishery Statistics: Catches and landings, 1979. Vol 48. FAO Fisheries Series No. 13. FAO Statistics Series No. 31.

United Nations. Food and Agriculture Organization. Fishery Statistics: Catches and landings, 1983. Vol 56. FAO Fisheries Series No. 23. FAO Statistics Series No. 58.

United Nations. Food and Agriculture Organization. Fishery Statistics: Catches and landings, 1993. Vol 76. FAO Fisheries Series No. 44. FAO Statistics Series No. 123.

Webster, J. R. and B. C. Pattern. 1979. Effects of watershed perturbation on stream potassium and calcium dynamics. Ecological Monographs. 49: 51-72. 


\title{
Appendix One
}

\author{
Water chemistry
}




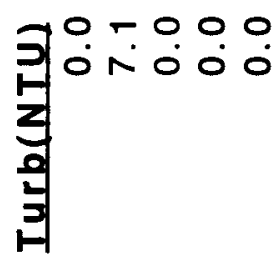

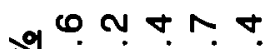
○ी

$\forall \ln N$

1001010

ल ल लिल

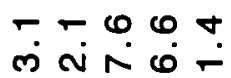

N un m

तं a 0 . ம்
$000 \infty \infty$

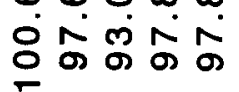
$\infty \forall$ n $\infty$ $m \forall \forall \forall$ $\pi d \theta+2$ $\infty-\forall-w$ ப் ச் ப் 단은은 $\infty-\infty m 0$

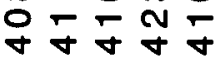

N Nं $\dot{\theta} \dot{0}$ के के के के

$\operatorname{con} 2$

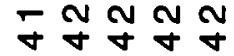

ma -0

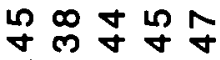
ம

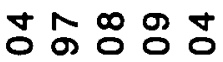
NंN

กิ $\dot{\omega} \dot{0} \dot{0} \dot{0}$ no 0 n 융요

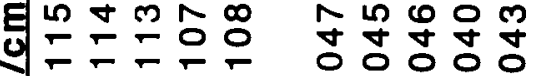
$N$ in $-a$ 눙 MN N 00000 ○ं 000

两 $\forall \bullet$ m 级 in - 00000 ०ं 0 0ं 00ं0்

구눙ㅇำ 그응응응 đั

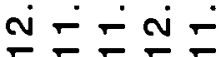

万的只的苋

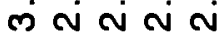

$\infty \infty \omega \forall N$ $\sim \infty 0 N O$

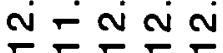

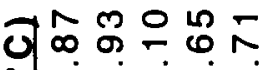
$\infty \infty \sigma a \sigma$

-

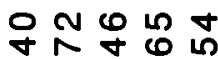
ヘm的 $\dot{\forall}$ மं 효

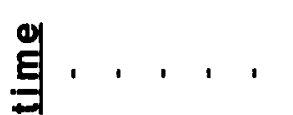

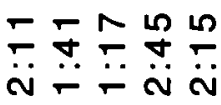

a -100 둔 $\because \ddot{\sim} \ddot{\sim} \dddot{\tau} \check{T}$

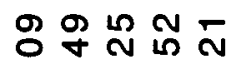
$\because \ddot{\sim} \ddot{\sim} \dddot{-}$

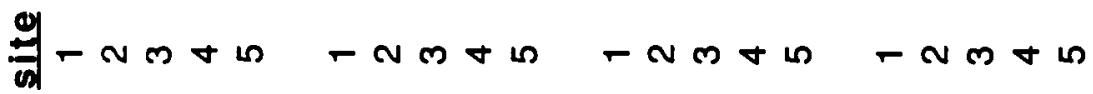
월 
Appendix Two

Diatom taxa of Still Creek:

list of taxa 


\section{Species list}

(Common to rare according to pot observations. Distribution varies with natural substrata.)

Very common species

Achnanthes lanceolata

Achnanthes minutissima

Cocconeis placentula

Common species

Achnanthes lewisiana

Diatoma hiemale

Gomphoneis herculeana var. septiceps

Gomphoneis herculeana var. robusta

Gomphonemia clevei

Gomphonemia oliviaceodes

Melosira ambigua

Melosira italica

Melosira varians

Meridion circulare

Navicula radiosa

Nitzschia dissipata

Nitzschia acicularioides

Rhoicosphenia curvata

Synedra arcus

Synedra ulna var. contracta

Not uncommon species

Cymbella mexicana

Cymbella minuta var. silesiaca

Epithemia turgida

Eutonia perpusilla

Fragelaria vaucheria

Hanneae arcus

Rhopalodia gibba

Synedra mazamaensis

\section{Rare species}

Amphora sp.

Edentata sp.

Gomphonemia acuminatum

Stauroneis anceps 


\title{
Appendix Three A
}

\author{
Diatom taxa of Still Creek: \\ scanning electron micrographs \\ (courtesy of Zach Oestreicher)
}



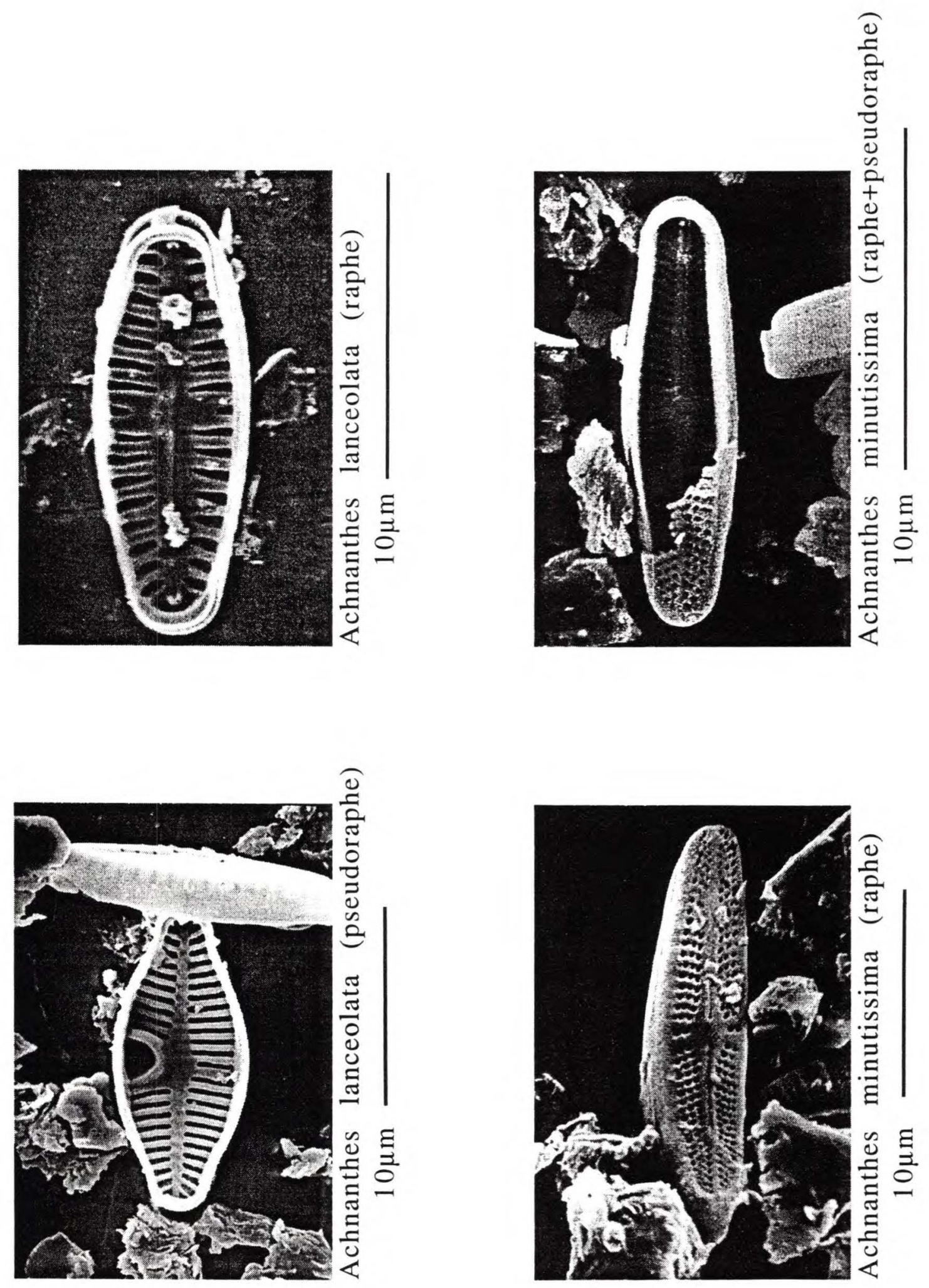

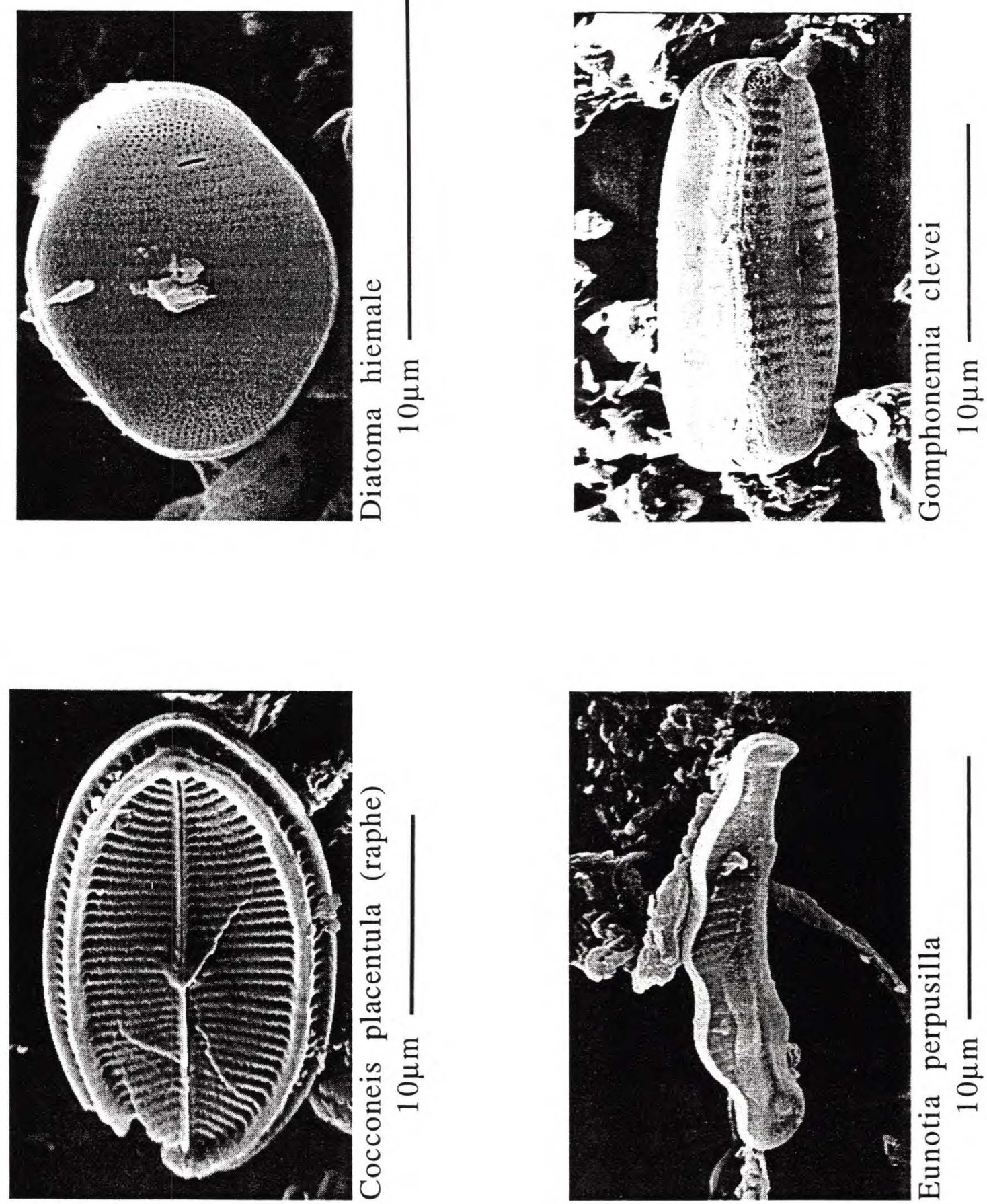
Appendix Three B

Diatom taxa of Still Creek: video graphic prints 


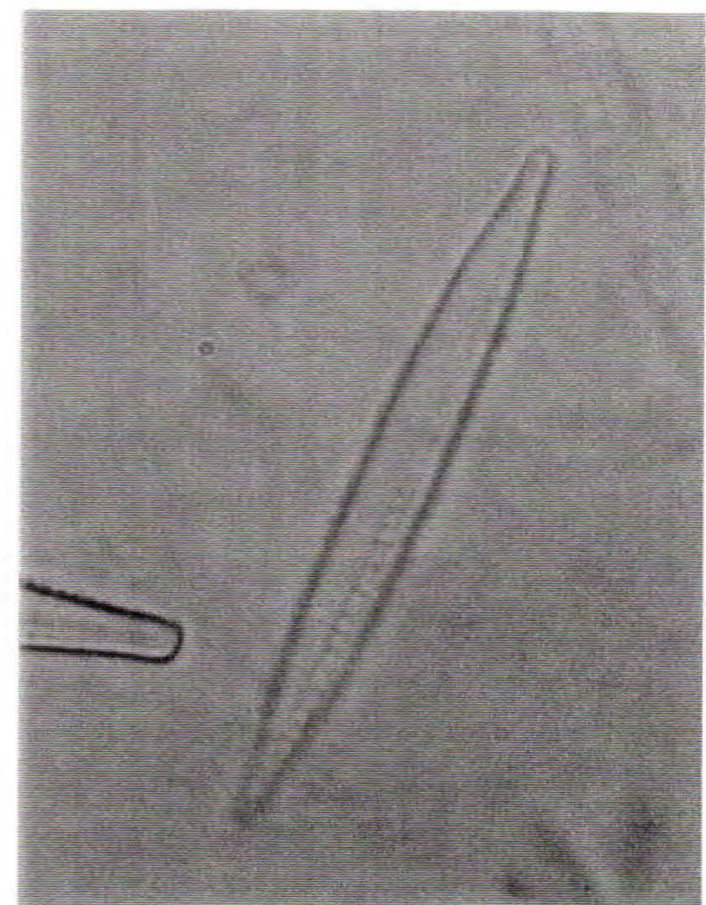

Nitzschia dissipata

$10 \mu \mathrm{m}$

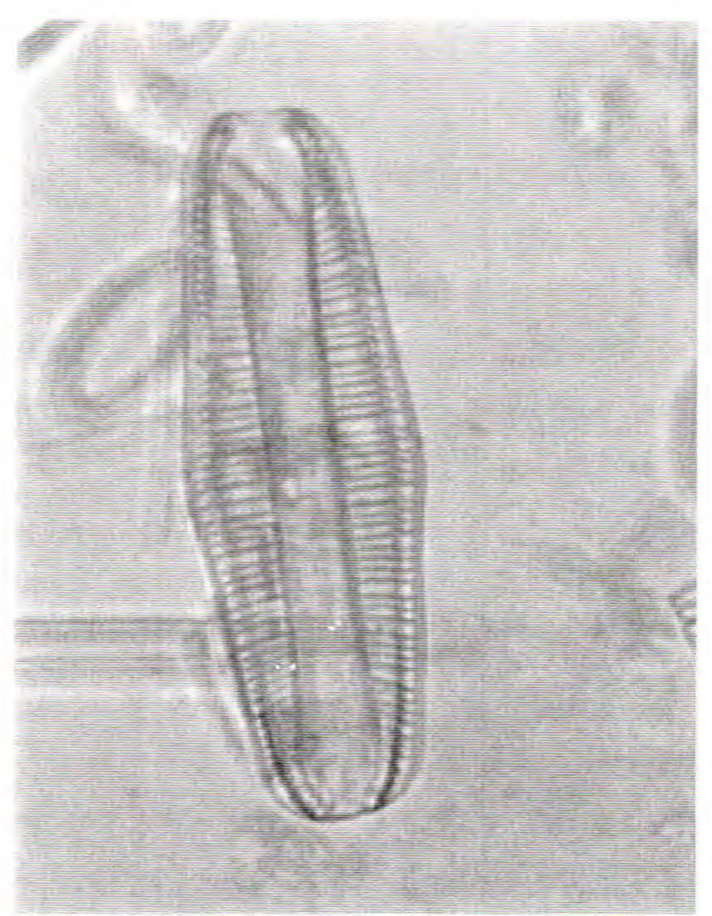

Rhopalodia gibba

$10 \mu \mathrm{m}$

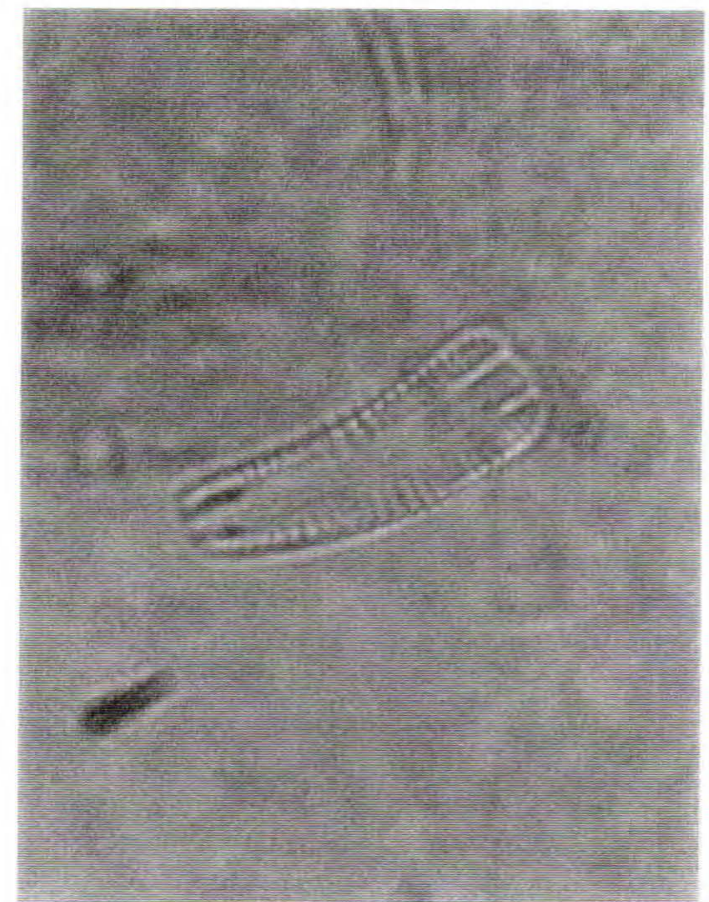

Rhoicosphenia curvata

$10 \mu \mathrm{m}$

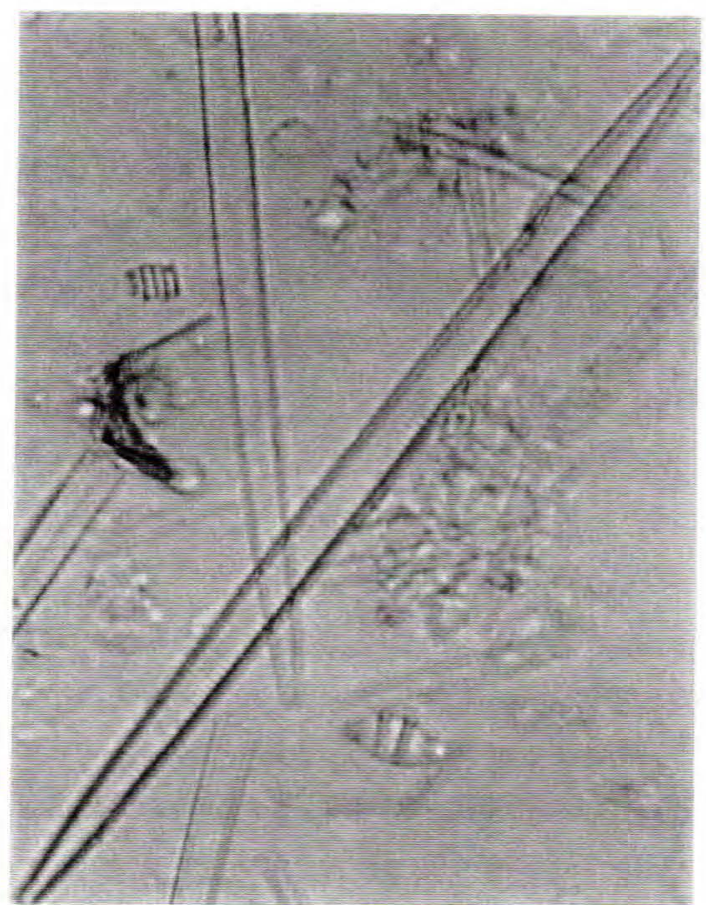

Synedra arcus

$10 \mu \mathrm{m}$ 


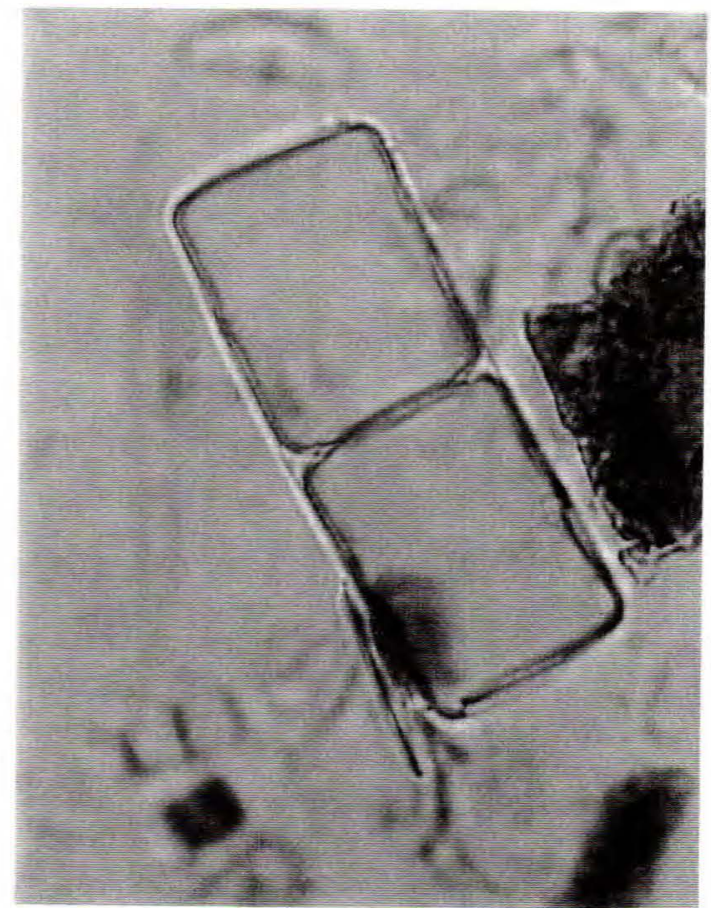

Melosira varians

$10 \mu \mathrm{m}$

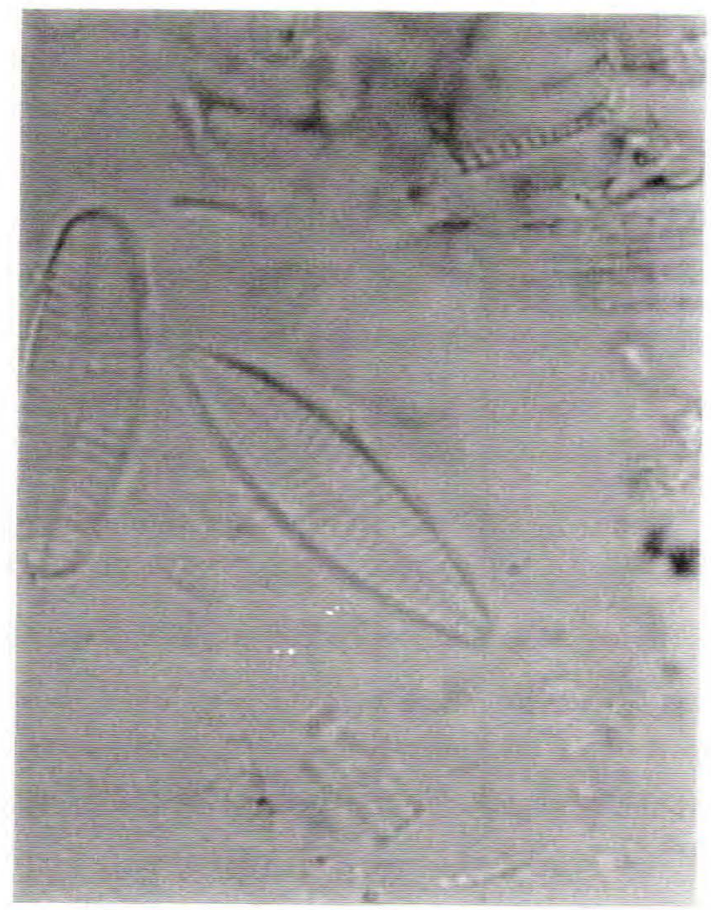

Navicula radiosa

$10 \mu \mathrm{m}$

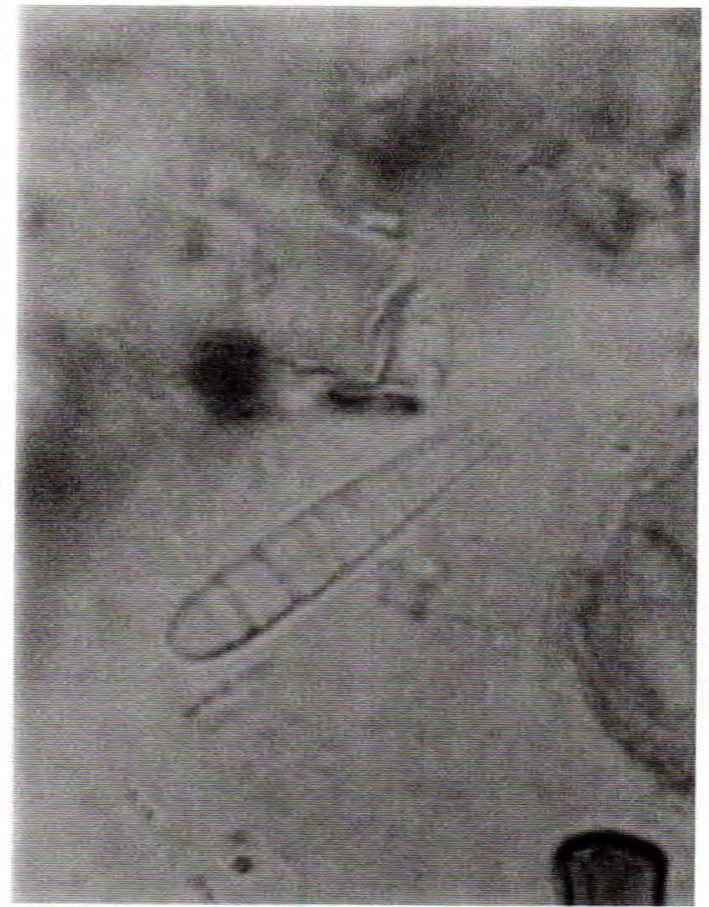

Meridion circulare

$10 \mu \mathrm{m}$

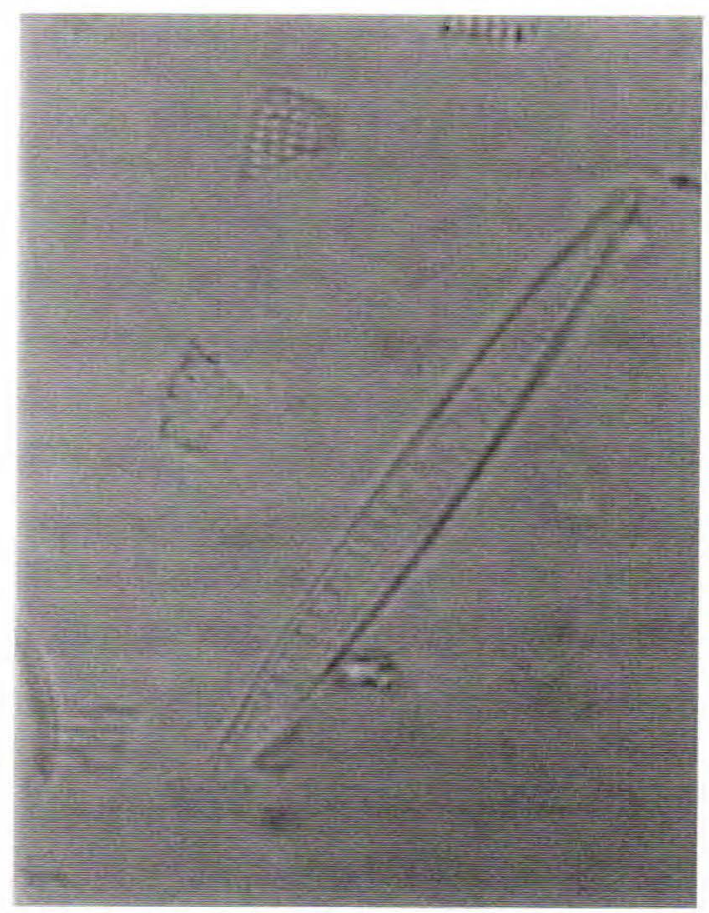

Nitzschia acicularioides

$10 \mu \mathrm{m}$ 


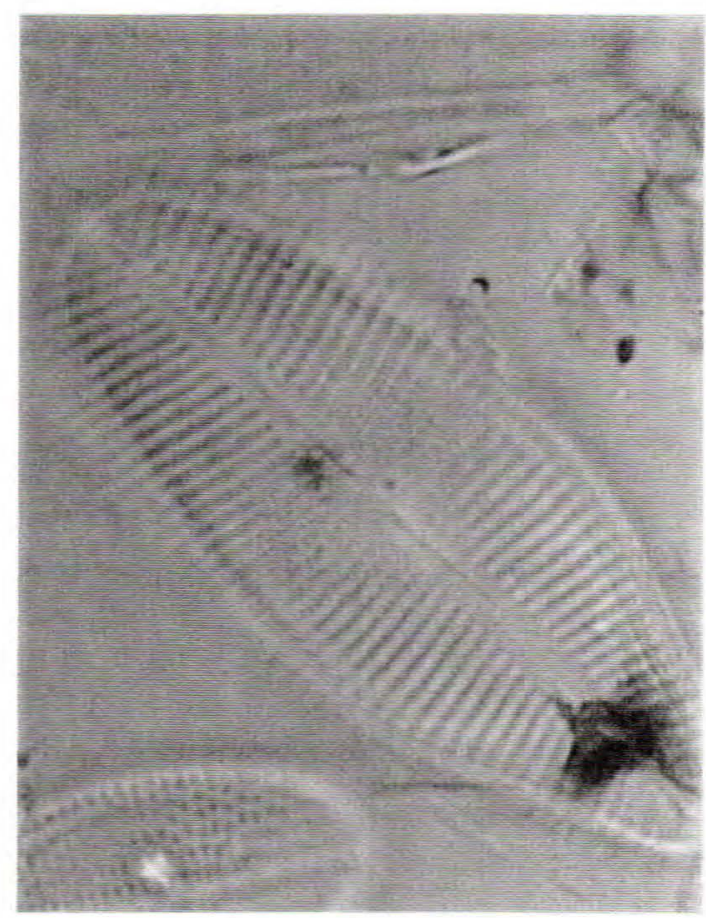

Gomphoneis herculeana v. robusta $10 \mu \mathrm{m}$
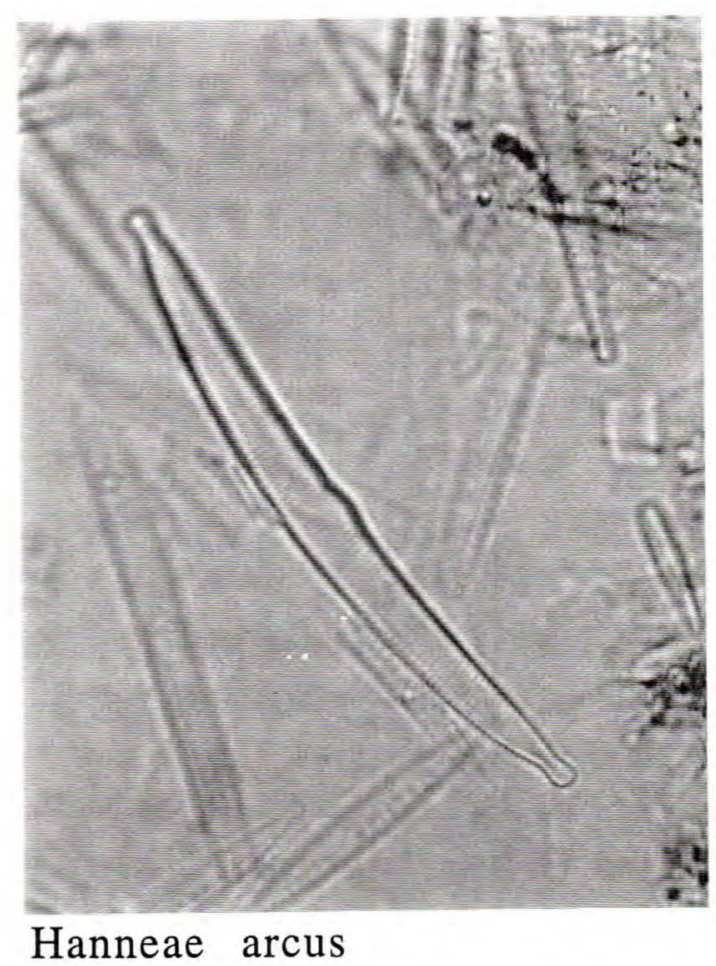

$10 \mu \mathrm{m}$

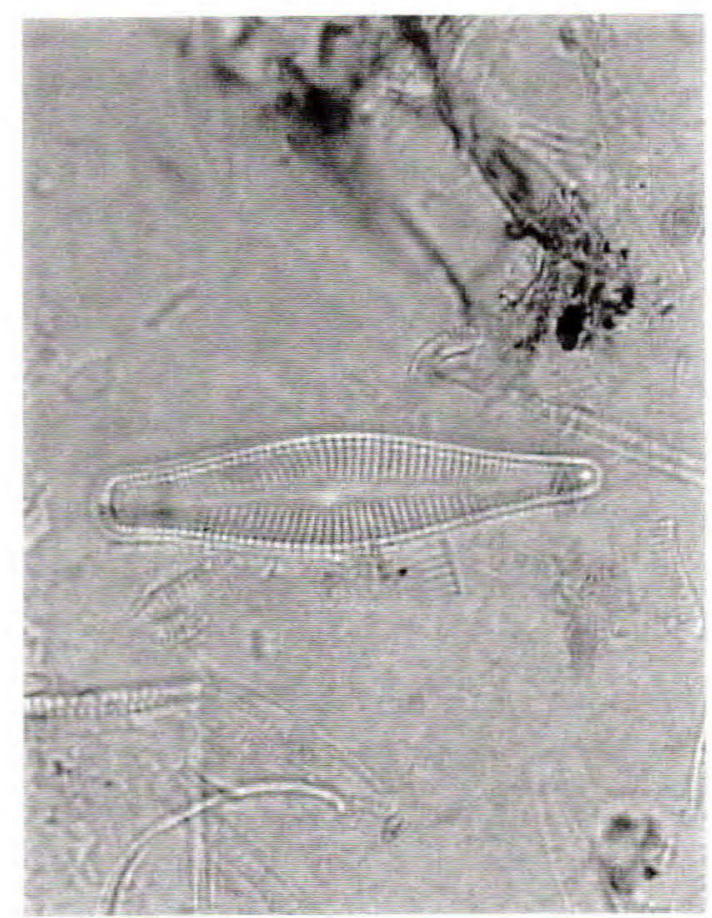

G. herculeana v. septiceps $10 \mu \mathrm{m}$
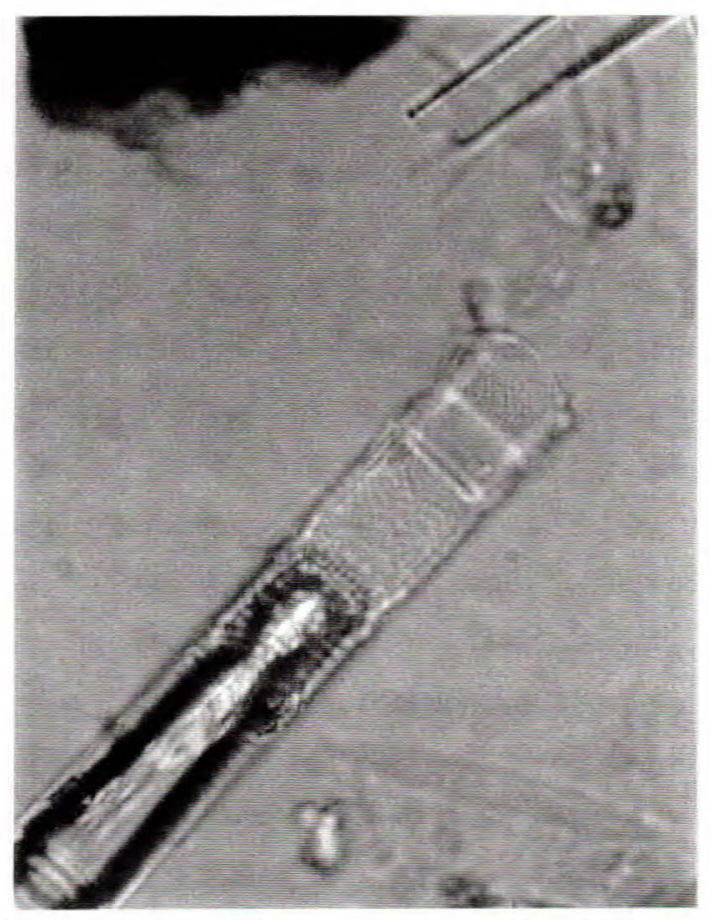

Melosira italica

$10 \mu \mathrm{m}$ 


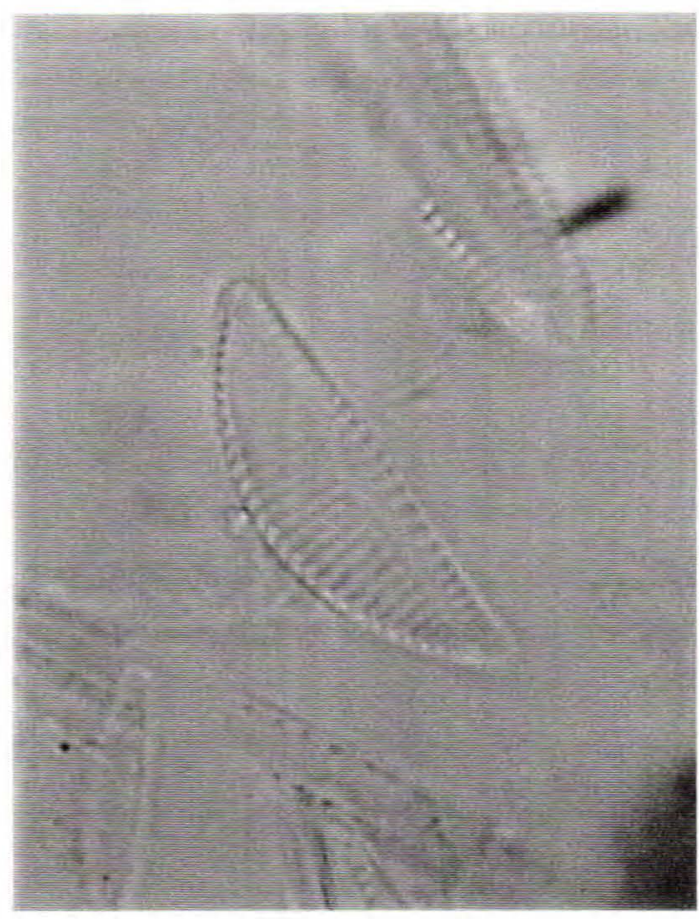

Cymbella minuta

$10 \mu \mathrm{m}$

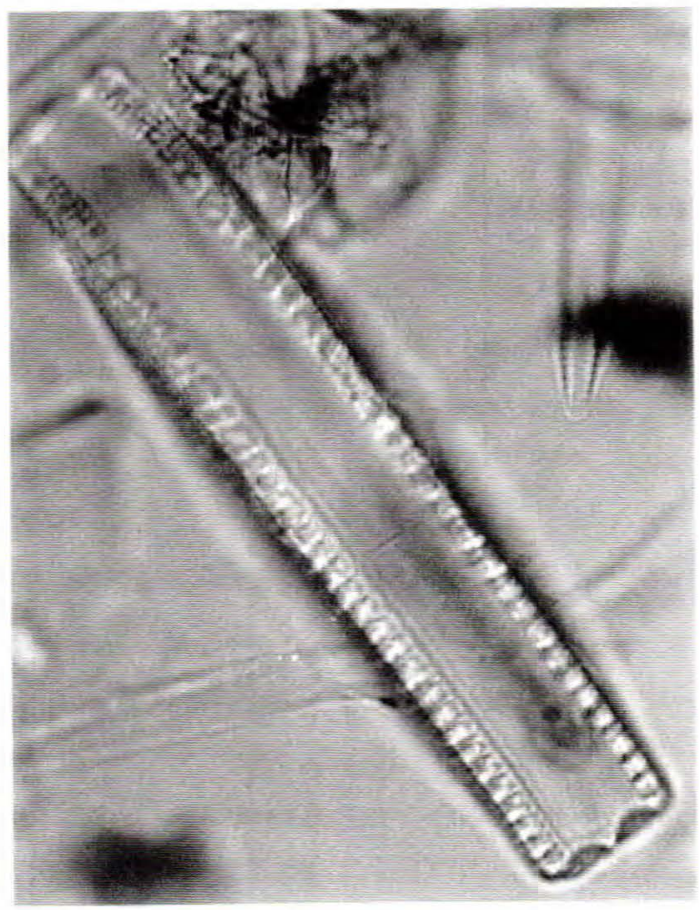

Edentata sp.

$10 \mu \mathrm{m}$

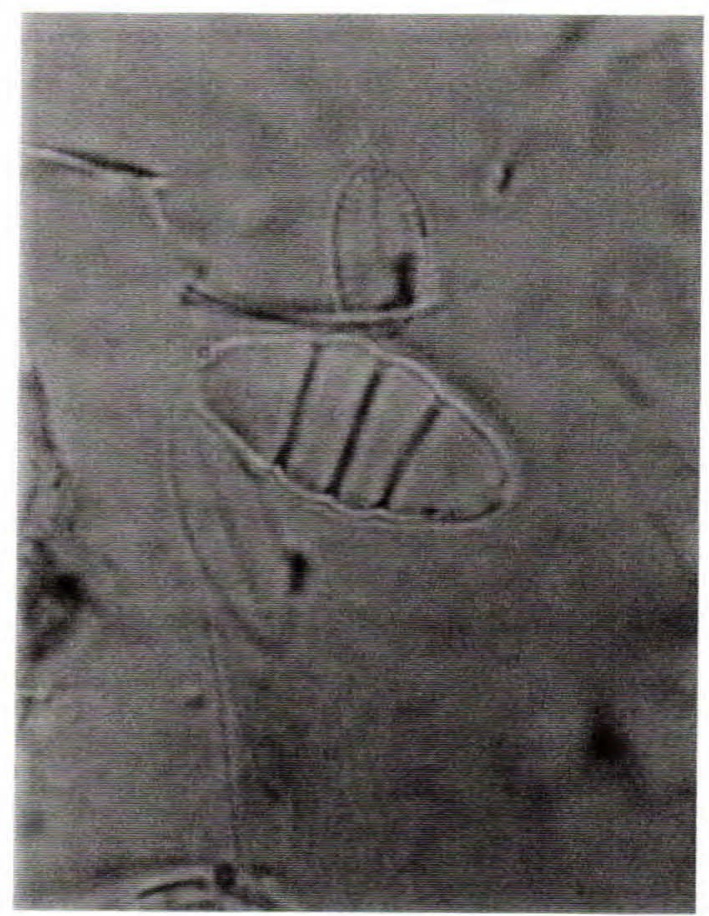

Diatoma hiemale $10 \mu \mathrm{m}$

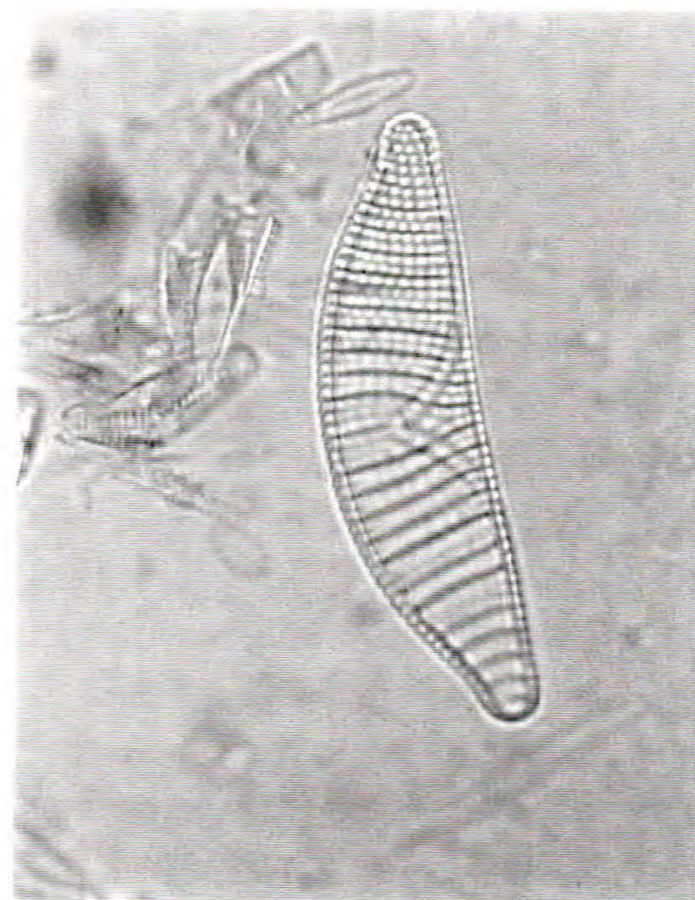

Epithemia turgida

$10 \mu \mathrm{m}$ 


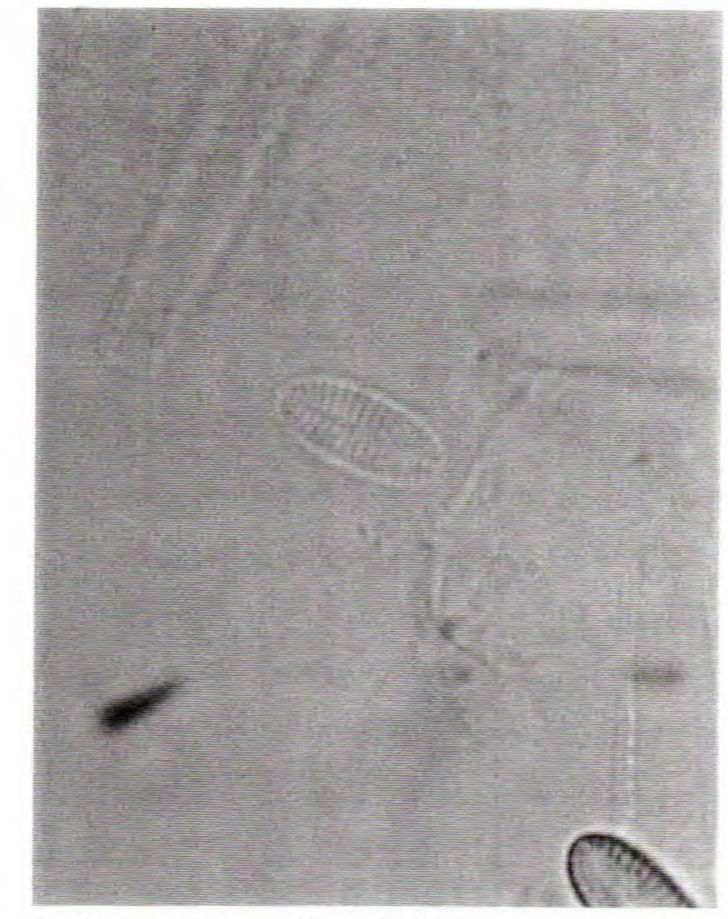

Achnanthes lewisiana $10 \mu \mathrm{m}$

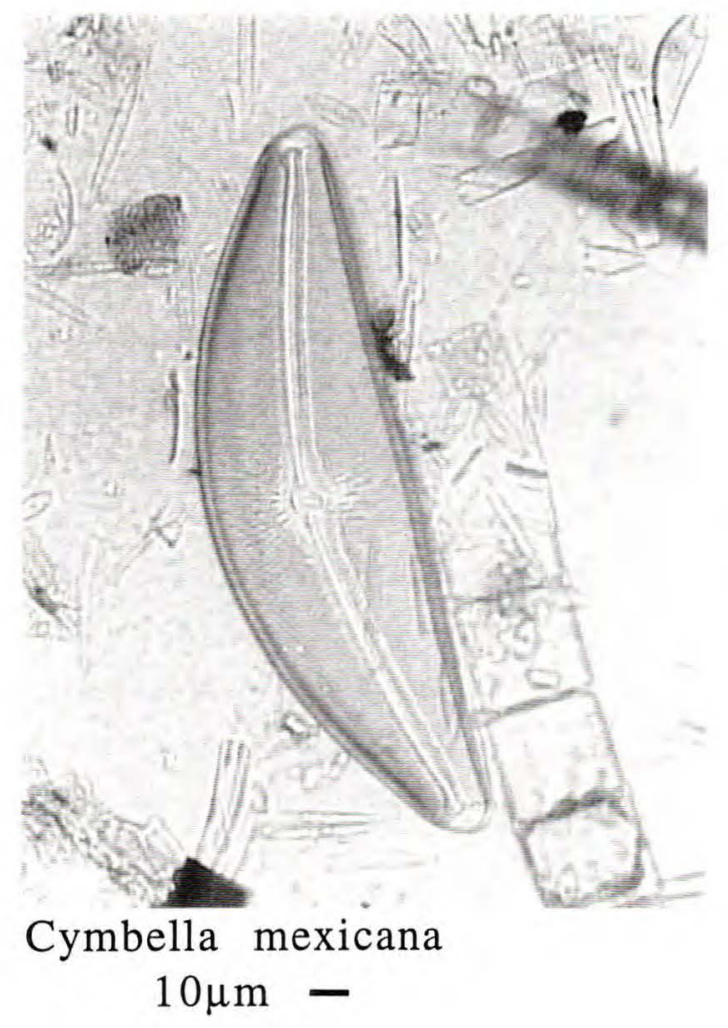

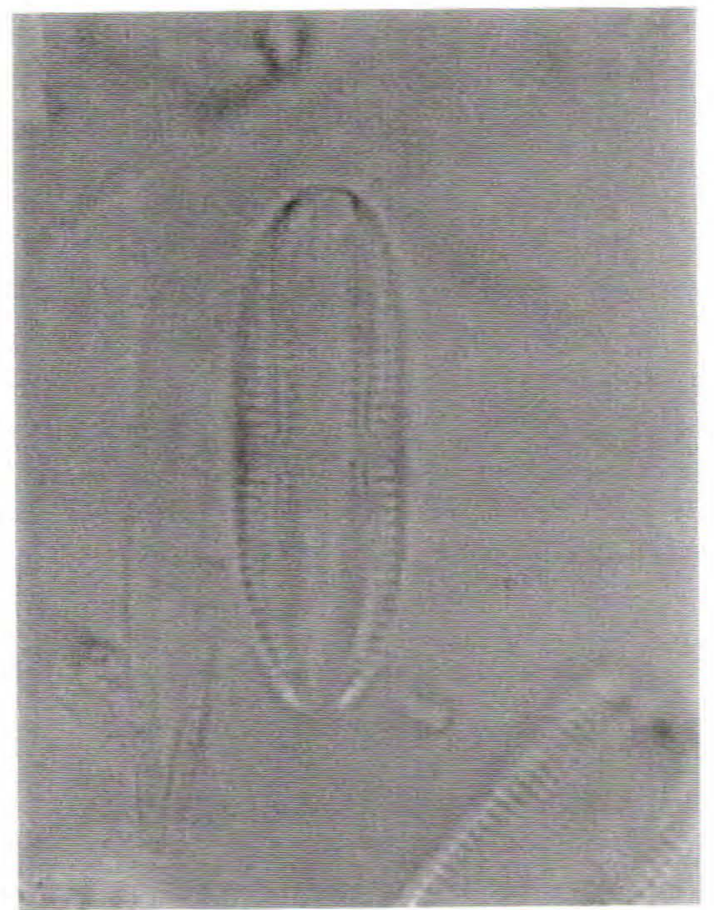

Amphora sp.

$10 \mu \mathrm{m}$

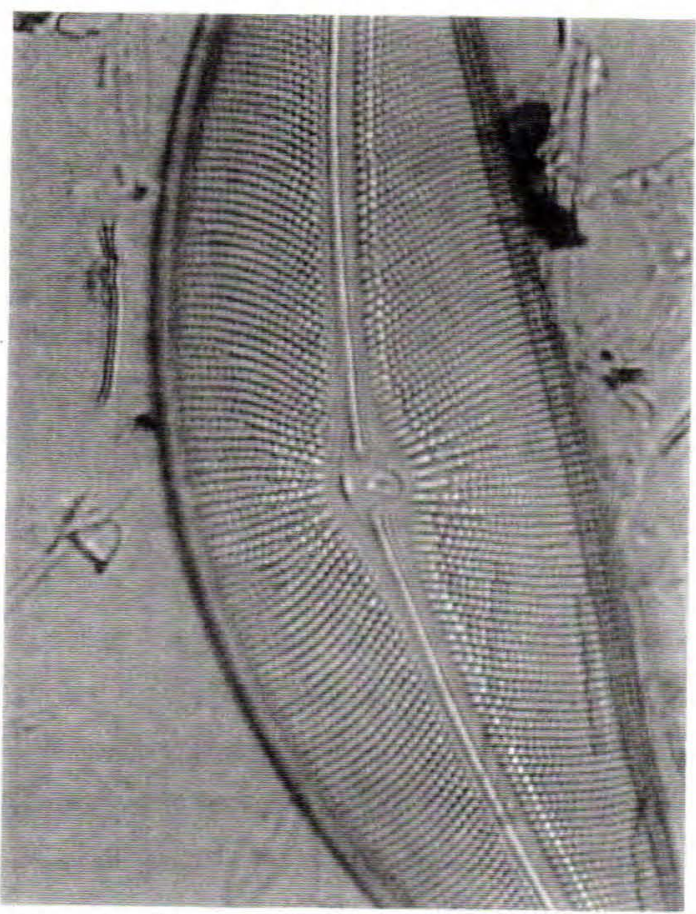

Cymbella mexicana

$10 \mu \mathrm{m}$ 


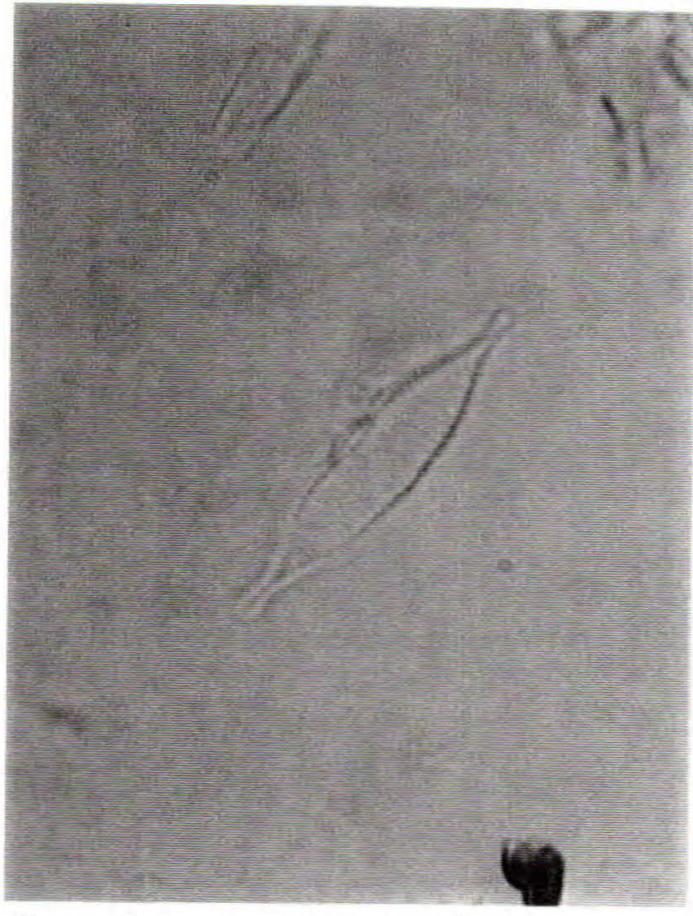

Synedra mazamaensis

$10 \mu \mathrm{m}$

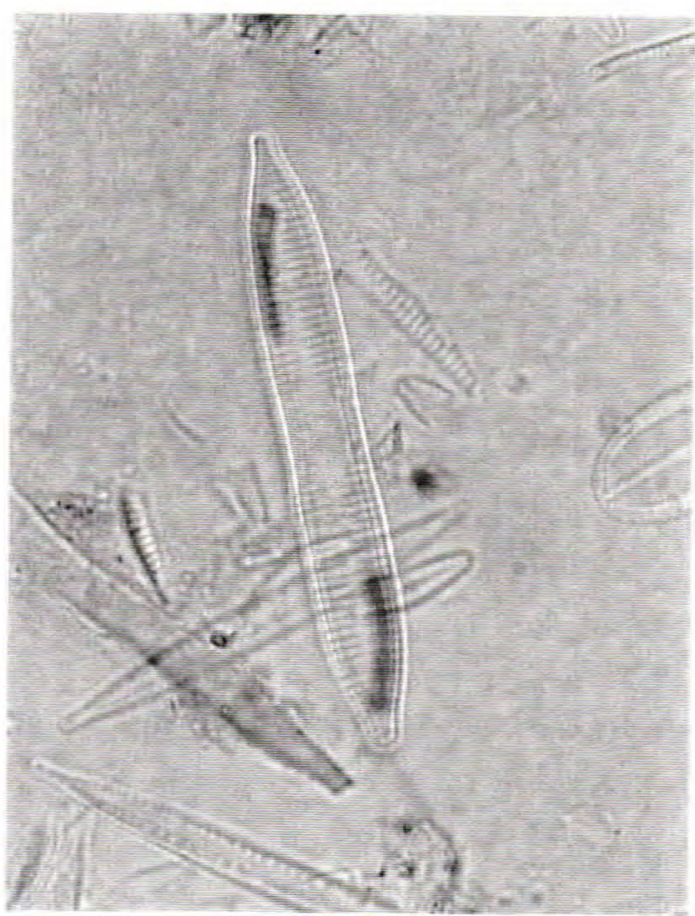

Synedra ulna v. contracta

$10 \mu \mathrm{m}$ 